\title{
Equine Squamous Gastric Disease: Prevalence, Impact and Management
}

\section{Michael Hewetson (D) \\ Rose Tallon}

Department of Clinical Science and Services, The Royal Veterinary College, North Mymms, Hertfordshire, UK
Correspondence: Michael Hewetson Department of Clinical Science and Services, The Royal Veterinary College, North Mymms, Herts, AL9 7TA, UK

Email mhewetson@rvc.ac.uk

\begin{abstract}
This narrative review explores the etiopathogenesis, clinical signs, diagnosis and treatment of ESGD (equine squamous gastric disease) and discusses the impact of this commonly encountered condition on the equine industry. ESGD refers specifically to peptic injury of the squamous mucosa of the stomach. Prevalence is highest in performance horses, but the disease has been documented across many breeds and ages, including in feral horses and foals. The pathogenesis of ESGD is well understood. Intensive management and exercise are important factors that contribute to a disruption of the normal stratification of gastric $\mathrm{pH}$. This results in exposure of the vulnerable squamous mucosa to acid, leading to ulceration. Clinical signs are variable and there is little evidence to support a direct association between reported signs and the presence or absence of lesions seen on gastroscopy. Management is aimed at acid suppression and mitigation of known risk factors.
\end{abstract}

Keywords: ulcer, stomach, ESGD, omeprazole, performance

\section{Introduction and Terminology}

Equine Gastric Ulcer Syndrome (EGUS) is a term that was first adopted in 1999 to describe erosive and ulcerative diseases of the equine stomach and is comparable to the term peptic ulcer disease in people. The terminology was recently expanded to include the terms Equine Squamous Gastric Disease (ESGD) and Equine Glandular Gastric Disease (EGGD) as it became clear there was a need to distinguish the anatomical region of the stomach affected. ${ }^{1,2}$ Although squamous and glandular gastric diseases can occur concurrently, there are significant differences in prevalence, epidemiology, pathogenesis, and treatment, and they should be seen as distinct disease entities. There is currently no clear relationship between the presence of ESGD and EGGD, and direct extrapolation from one disease to another is therefore inappropriate. ESGD refers specifically to peptic injury of the squamous mucosa of the stomach and is the focus of this review.

\section{Relevant Anatomy and Physiology}

The horse is a monogastric animal, and the stomach is comprised of four distinct anatomical regions; the dorsal fundus, the ventral fundus, the cardia and the pylorus (Figure 1). The mucosal lining is divided into a dorsal squamous and a ventral glandular portion by the margo plicatus. The dorsal squamous portion has a smooth, glistening surface and is pale yellow to white in color. It is comprised of stratified squamous epithelium and is contiguous with the esophagus at the level of the cardia. Histologically, the squamous epithelium consists of layers of 


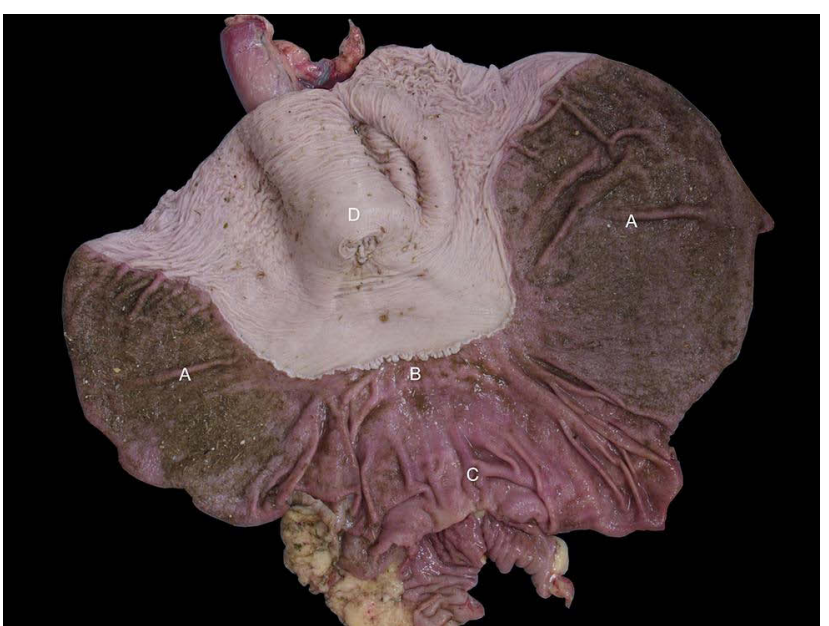

Figure I The normal equine stomach showing the four distinct anatomical regions. A, ventral fundus, B, cardia; C, pylorus; D, dorsal fundus. Image adapted with permission of Equine Veterinary Journal. Martineau $\mathrm{H}$, Thompson $\mathrm{H}$, Taylor D. Pathology of gastritis and gastric ulceration in the horse. Part I: range of lesions present in 21 mature individuals. Equine Vet J. 2009;4I(7):638-644. ${ }^{23}$

keratinized and non-keratinized epithelial cells, an underlying lamina propria and a muscularis mucosa. The epithelium varies in thickness from $309 \mu \mathrm{m}$ to $1154 \mu \mathrm{m}$, and is thickest immediately adjacent to the margo plicatus, presumably as an adaptation to increased acid exposure in this region. ${ }^{3}$ There is no inflammatory cell infiltration in the epithelium or the lamina propria of healthy equine squamous epithelium. ${ }^{3}$

The squamous mucosa has no absorptive or secretory capacity and simply acts as a protective barrier. In contrast, the glandular mucosa is comprised of mucus producing cells and gastric glands and is responsible for secreting hydrochloric acid (HCL) in response to gastrin. Horses are basal acid secretion and as such, they secrete acid constantly irrespective of feed consumption. ${ }^{4}$ The $\mathrm{pH}$ in the ventral stomach of adult horses is therefore predominately acidic and remains relatively stable, with a median $\mathrm{pH}$ of 2.9 over a 24 -hour period..$^{5}$ In contrast, $\mathrm{pH}$ in the dorsal stomach is less acidic, with a median $\mathrm{pH}$ of 6.8 , however it is exposed to large diurnal fluctuations, likely due to the natural feeding patterns of horses. Horses consume most of their roughage during the day. ${ }^{6}$ Once ingested, it forms a fibrous mat within the stomach that helps maintain normal $\mathrm{pH}$ stratification of gastric content, thereby facilitating buffering of acid in the dorsal stomach. ${ }^{7}$ As a consequence, horses have a significantly higher $\mathrm{pH}$ in the dorsal stomach during the day, and this may persist for up to five hours after feeding. ${ }^{5}$ In addition to endogenous acid secretion, gastric $\mathrm{pH}$ in the dorsal stomach is also influenced by saliva, short-chain fatty acids (SCFA), lactic acid and duodenal reflux of biliary secretions. $^{8-12}$

In contrast to adult horses, gastric $\mathrm{pH}$ in the proximal and distal stomach of neonatal foals is highly variable, with a mean $\mathrm{pH}$ of 5.5. ${ }^{13}$ The squamous mucosa is thin at birth and becomes progressively thicker as the foal gets older, presumably as an adaptation to increased acid exposure. $^{14}$

\section{Gross Pathology and Histopathology}

Characteristic lesions associated with ESGD include hyperkeratosis, erosion, and ulceration. Lesions are most commonly seen adjacent to the margo plicatus along the lesser curvature and greater curvature of the stomach in both adults and foals; and tend to be more severe at the lesser curvature in the region of the cardia. ${ }^{15-22}$

\section{Hyperkeratosis}

Hyperkeratosis is caused by thickening of the keratinized layers of the squamous epithelium (the stratum corneum) and can be recognized macroscopically as diffuse regions of thickened, corrugated tissue (Figure 2). The affected epithelium is often friable and has a characteristic yellow discoloration. Histologically, these lesions are characterized as parakeratotic or orthokeratotic hyperkeratosis (Figure 3). ${ }^{23}$ The exact cause of hyperkeratosis is unclear, however it is likely to be a response to excessive exposure to acid and as such, may be an early manifestation of acid injury. ${ }^{23}$

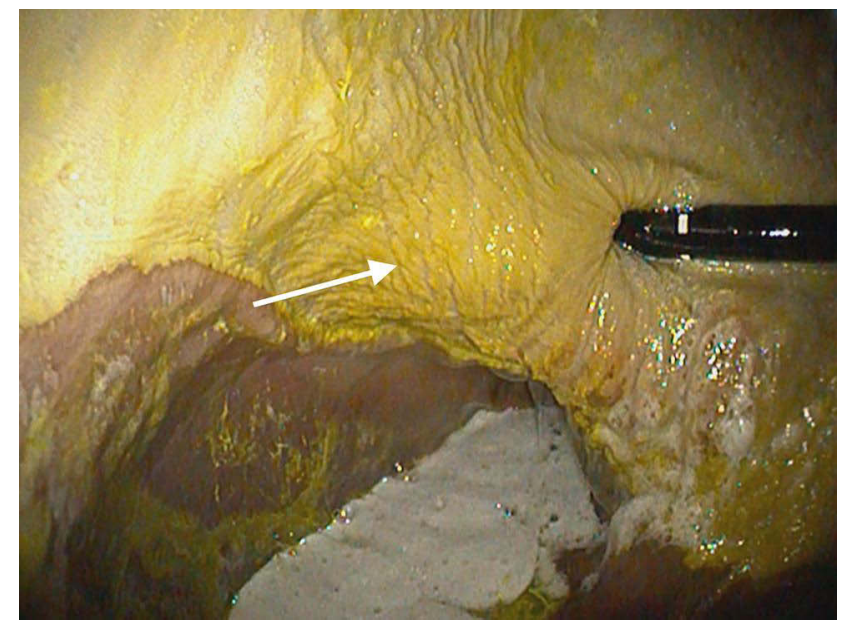

Figure 2 Hyperkeratosis (white arrow). Notice the thickened, corrugated squamous mucosa surrounding the cardia. Regions of hyperkeratosis often have a characteristic yellowish discoloration. Image property of the author. 


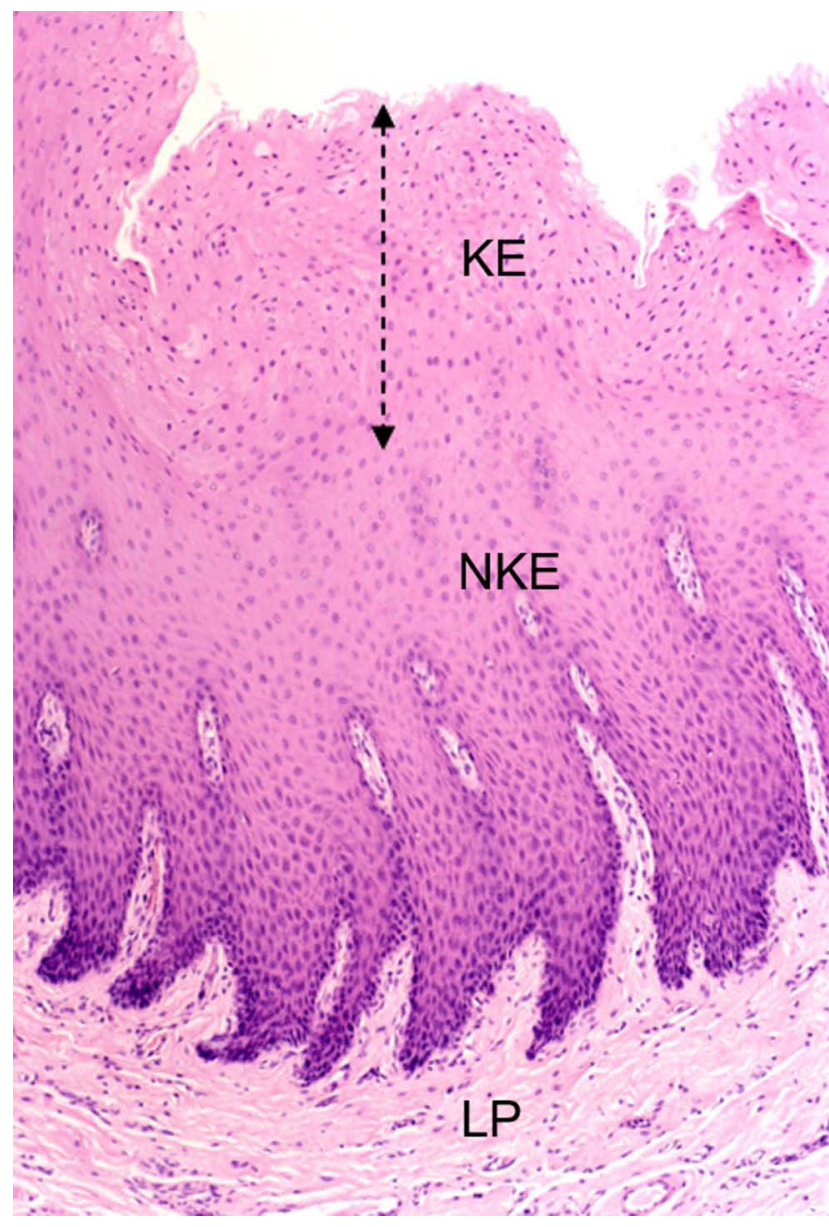

Figure 3 Parakeratotic hyperkeratosis (dashed arrow). Bar $=400 \mu \mathrm{m}$. Image reproduced with permission of Equine Veterinary Journal. Martineau $\mathrm{H}$, Thompson H, Taylor D. Pathology of gastritis and gastric ulceration in the horse. Part I: range of lesions present in 21 mature individuals. Equine Vet J. 2009;4I(7):638-644. ${ }^{23}$

Abbreviations: K, keratinized epithelium; NKE, non-keratinized epithelium; LP, lamina propria.

\section{Erosions}

Erosions are superficial defects in the squamous mucosa involving the epithelium and basement membrane, but do not extend beyond the lamina propria. Erosions have a smooth reddish/pink macroscopic appearance and can be focal or diffuse (Figure 4). Histologically, they are characterized by thinning and lifting of the keratinized layer of the epithelium and an influx of polymorphonuclear cells within the epithelium and the lamina propria (Figure 5). ${ }^{3,23}$ Erosions represent a milder form of acid injury and will progress to ulceration with ongoing acid exposure.

\section{Ulceration}

Ulcers are deeper defects in the squamous mucosa that extend beyond the lamina propria. Ulcers have a characteristic

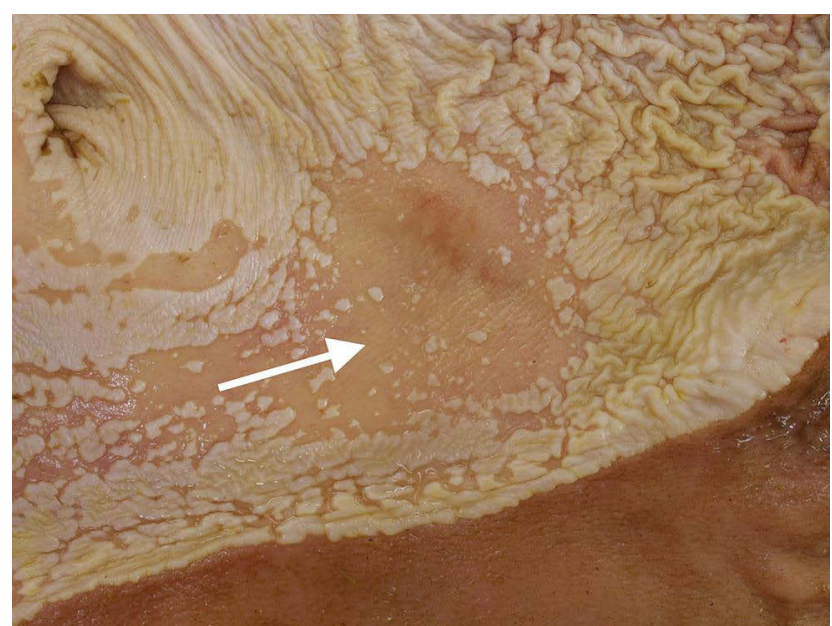

Figure 4 Erosion (white arrow). Notice the focal region of squamous mucosa that is smooth and reddish/pink in appearance. This represents thinning of the squamous epithelium and loss of the keratinized layer. Image courtesy of Henny Martineau.

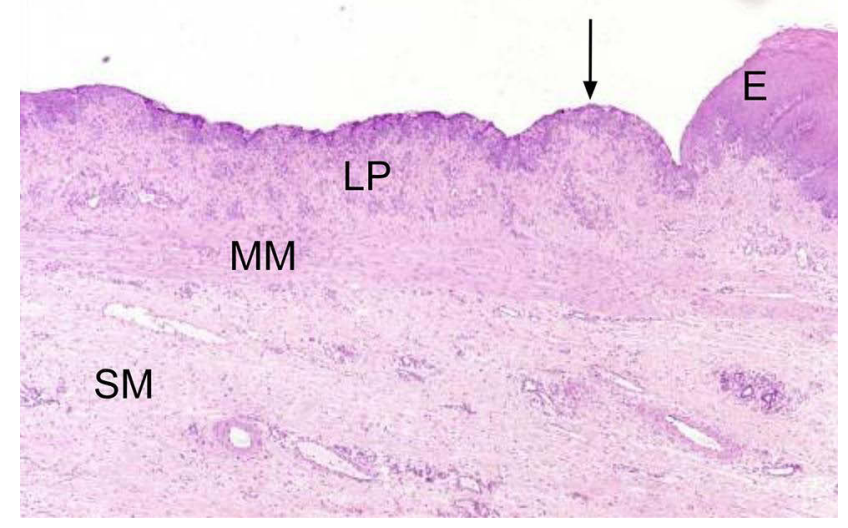

Figure 5 Erosion (black arrow) adjacent to normal squamous epithelium. Bar = $1000 \mu \mathrm{m}$. Notice the dramatic thinning of the affected epithelium. Image reproduced with permission of Equine Veterinary Journal. Martineau $\mathrm{H}$, Thompson $\mathrm{H}$, Taylor D. Pathology of gastritis and gastric ulceration in the horse. Part I: range of lesions present in 21 mature individuals. Equine Vet J. 2009;4I (7):638-644. ${ }^{23}$

Abbreviations: E, epithelium; LP, lamina propria; MM, muscularis mucosa; SM, submucosa.

depressed center surrounded by a prominent margin of tissue and may be associated with active hemorrhage when severe (Figures 6 and 7). Histologically, there is complete epithelial loss, and the underlying muscularis mucosa is exposed (Figure 8). ${ }^{3,23}$ Over time, a bed of granulation tissue develops that is covered with neutrophils, fibrin and necrotic debris, and bacteria can sometimes be seen invading the keratinized epithelium at the edge of the ulcer. ${ }^{3,23}$ The mucosa immediately adjacent to the ulcer responds by developing prominent epithelial projections that extend into the lamina propria and capillaries that extend from the lamina propria into the epithelium. Furthermore, the keratinized and non-keratinized 


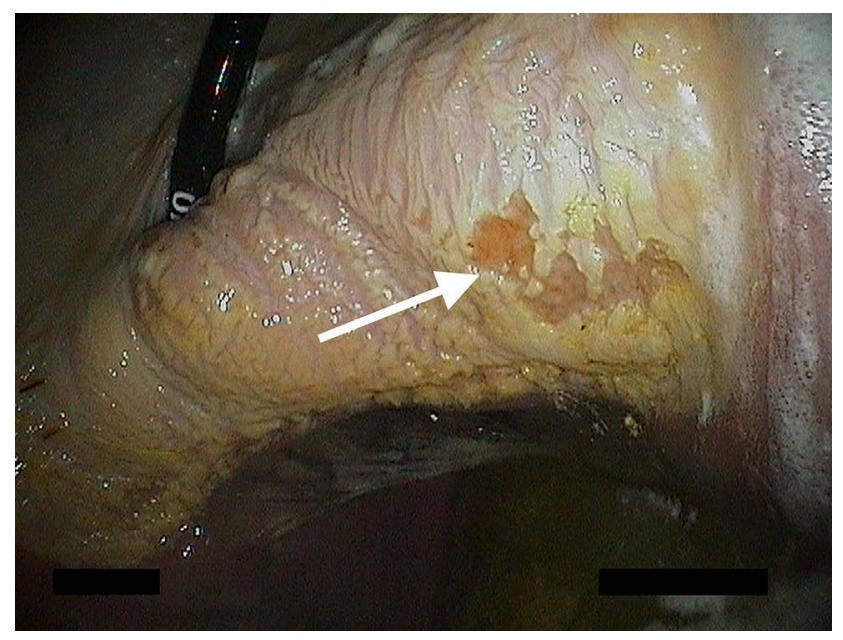

Figure 6 Ulcer (white arrow). Notice the characteristic depressed center surrounded by a prominent margin of tissue. Image property of the author.

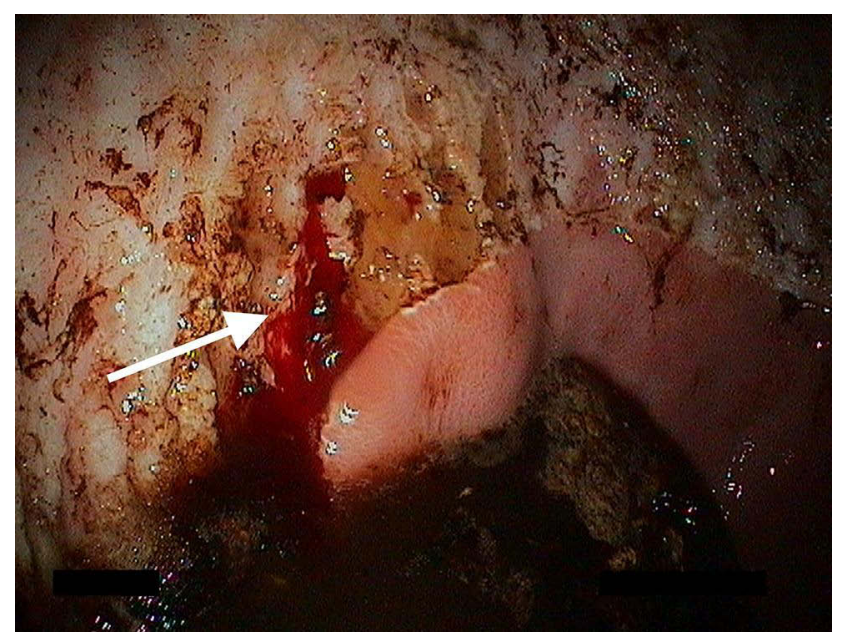

Figure 7 Bleeding ulcer (white arrow). Ulcers may be associated with active hemorrhage when severe. Image property of the author.

epithelium increases in thickness, giving the ulcer margin a characteristic proliferative appearance. ${ }^{3}$ In rare cases, deep ulcers may perforate the stomach and lead to a fatal septic peritonitis. It is most commonly seen in foals and is extremely uncommon in adult horses. ${ }^{24}$ Strictures can form as a sequel to ESGD, although this is rarely reported in the squamous portion of the stomach. ${ }^{25}$ Glandular metaplasia is sometimes seen in horses and should not be mistaken for ulceration. Glandular metaplasia is characterised by the development of islands of glandular mucosa that are interspersed within the stratified squamous epithelium along the margo plicatus, particularly in the region of the cardia. The clinical significance of this finding in the horse is unclear at present, however it may represent an adaptation to continual exposure of the squamous epithelium to acid. ${ }^{23}$ In people, a similar condition exists

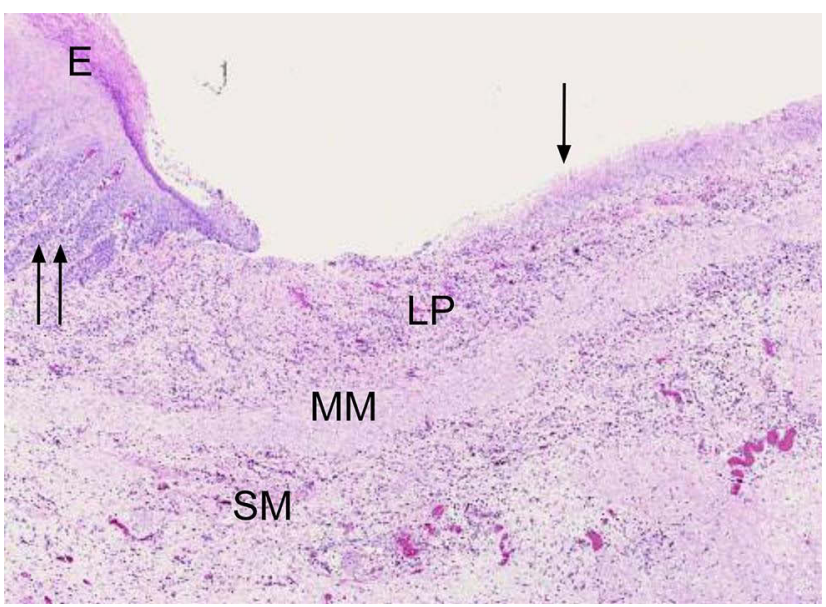

Figure 8 Ulcer (single black arrow) adjacent to normal squamous epithelium. Notice the complete loss of epithelium in the ulcer bed and exposure of the underlying lamina propria. Prominent epithelial projections can be seen in the normal mucosa immediately adjacent to the ulcer (double black arrows). Bar = $1000 \mu \mathrm{m}$. Image reproduced with permission of Equine Veterinary Journal. Martineau H, Thompson H, Taylor D. Pathology of gastritis and gastric ulceration in the horse. Part I: range of lesions present in 21 mature individuals. Equine Vet J. 2009;4I(7):638-644. ${ }^{23}$

Abbreviations: E, epithelium; LP, lamina propria; MM, muscularis mucosa; SM, submucosa.

called Barrett's esophagus, which occurs in response to chronic inflammation associated with gastroesophageal reflux disease (GERD) and represents a pre-neoplastic change. ${ }^{26}$ A potential association between Equus caballus papillomavirus type 2 (EcPV-2) infection and a subset of horses with gastric squamous cell carcinoma (SCC) has been recently reported. ${ }^{27,28}$ It is unclear whether squamous epithelial injury might play a role in the development of SCC. Squamous epithelial hyperplasia or metaplasia has been suggested as a precursor of carcinoma development, although further work is needed to characterise the gross appearance of early pre-neoplastic change in the equine stomach and to explore the link between squamous ulceration and SCC.

\section{Pathogenesis}

Equine squamous gastric disease is a consequence of sustained exposure of the squamous mucosa to acid and is comparable to gastric ulceration of the pars esophagea in pigs and GERD in people. As is the case with other species, the squamous mucosa of the equine stomach is inherently vulnerable to acid injury as it has a poor blood supply and does not possess a mucus-bicarbonate layer in order to protect itself. ${ }^{29}$ The thick keratinized epithelium together with the presence of high electrical resistance, tight epithelial junctions and an osmophilic phospholipid surfactant-like layer provide some protection, however this 
mucosal barrier is rapidly overwhelmed in the presence of acid, with evidence of injury occurring after as little as 30 minutes of exposure. ${ }^{7,30,31}$

Acid injury is primarily attributable to endogenous HCL, which erodes the outer keratinized layers of the squamous epithelium and results in disruption of the bioelectric properties of the transporting cells, thus compromising barrier function. ${ }^{8,10,30}$ In addition, other gastric constituents, including SCFA, lactic acid and bile salts, have been shown to act synergistically with HCL, thus further attenuating barrier function and ultimately resulting in cellular injury. ${ }^{8-12}$ For example, SCFA have been shown to be relatively harmless to the squamous epithelium at a $\mathrm{pH}>4$, however they become lipid soluble at a $\mathrm{pH} \leq 4$, and are then able to penetrate cells, causing cellular injury. ${ }^{7,10,11}$ Bile acids have a similar deleterious effect on the squamous mucosa in their unionized lipid soluble state. ${ }^{7,12}$

The sequence of events following exposure of squamous epithelial cells to acid is the movement of $\mathrm{H}^{+}$ions across the cell membrane, acidification of cellular contents, inhibition of sodium transport, cellular swelling and ultimately cell death. ${ }^{7}$ The squamous epithelium initially reacts by thickening and becoming hyperkeratotic. Sloughing of superficial layers of epithelium result in the development of erosions, and with continued acid exposure, lesions deepen to form ulcers. ${ }^{23}$

Equine squamous gastric disease can be either primary or secondary. ${ }^{1}$ Primary ESGD occurs in response to risk factors inherent in domestication and intensive management that result in prolonged exposure of the squamous mucosa to acid in horses with an otherwise normal gastrointestinal tract. In contrast, secondary ESGD occurs as a direct consequence of delayed gastric emptying. This causes chronic gastric distension resulting in prolonged exposure of the squamous mucosa to acid. The most common cause of delayed gastric emptying in adult horses and foals is pyloric outflow obstruction secondary to glandular gastric disease. ${ }^{24,32-34}$

\section{Prevalence and Risk Factors}

Prevalence studies can be challenging to interpret as not all reports make a clear distinction between ESGD and EGGD. Interpretation is further complicated by the fact that the prevalence of ESGD within specific subpopulations of horses may vary over time in response to changes in management or the intensity of training. It has also been suggested that the prevalence of ESGD may be overstated in some populations, as many studies include horses with mild ( $\leq$ grade $2 / 4$ ) lesions that may be of questionable clinical significance. ${ }^{35}$ Table 1 summarises prevalence data and reported risk factors for ESGD in adult horses and foals.

The prevalence is highest in performance horses and reflects changes in management and intensity of exercise inherent in competition. It has been shown that the risk of ESGD increases with an increase in the intensity of exercise and the duration of time at work. ${ }^{36,37}$ This association is well recognized in Thoroughbred and Standardbred racehorses, ${ }^{20,37-41}$ but has also been shown in elite endurance horses, ${ }^{42}$ show jumping warmbloods ${ }^{38}$ and other nonracing performance horses. ${ }^{43}$ Strenuous exercise causes an increase in intraabdominal pressure associated with contraction of the abdominal muscles. This results in gastric compression and exposure of the sensitive squamous mucosa to acidic gastric content. ${ }^{44}$ Strenuous exercise has also been shown to cause an increase in postprandial gastrin secretion, resulting in an increased production of HCL. ${ }^{45}$

Several additional factors associated with management have also been shown to increase the risk of ESGD, many of which are imposed on horses at the commencement of training or during active competition. These include the trainer, high starch/low roughage diets, fasting, stall confinement, transport, intermittent access to water and administration of hypertonic solutions of electrolytes. ${ }^{36,46-49}$ Exposure to a combination of a high starch diet, stall confinement and strenuous exercise has been shown to induce lesions in as little as 7 days; and intermittent fasting is so effective at inducing lesions that it is used as a model for ESGD in experimental studies. ${ }^{50,51}$ Intermittent fasting disrupts normal $\mathrm{pH}$ stratification of gastric content, thereby allowing high concentrations of HCL and refluxed bile to mix in the dorsal stomach. ${ }^{7,50}$ Low roughage diets also disrupt normal $\mathrm{pH}$ stratification by causing greater gastric fluidity and mixing of dorsal and ventral gastric contents, but in addition to this, horses chew less, and this results in decreased production of saliva, which is an important buffer of acid in the dorsal stomach. ${ }^{7}$ Ingestion of large quantities of fermentable carbohydrate (starch $>1 \mathrm{~g} / \mathrm{kg} /$ meal) exacerbates the situation further by causing rapid production of SCFA, which acts synergistically with HCL in the presence of a low $\mathrm{pH}$ to cause acid injury of the squamous epithelium. ${ }^{46}$ High concentrate diets also stimulate secretion of gastrin which results in further acid secretion. ${ }^{52}$ 
Table I Prevalence of ESGD in Different Populations of Horses and Associated Risk Factors

\begin{tabular}{|c|c|c|c|c|}
\hline Population & Prevalence & Risk Factors & Limitations & Ref. \\
\hline \multicolumn{5}{|l|}{ Racehorses } \\
\hline TB & $\begin{array}{l}52-92 \% \\
\text { Prevalence } 92 \% \text { in } \\
\text { symptomatic horses and } \\
52 \% \text { in asymptomatic } \\
\text { horses }\end{array}$ & Active training & & [4I] \\
\hline TB & $93 \%$ & Active racing within the previous 2 months & Small sample size $(n=67)$ & [53] \\
\hline TB & $82 \%$ & & & [54] \\
\hline SB & $87 \%$ & Horses $\geq 3$ years old; geldings & & [59] \\
\hline SB & $44 \%$ & $\begin{array}{l}\text { Active racing [OR 9.3]; gait - trotters more } \\
\text { likely to have ESGD than pacers [OR 2.2]; } \\
\text { poor body condition; horses living at } \\
\text { racetracks; increasing age }\end{array}$ & & [39] \\
\hline $\mathrm{TB}, \mathrm{SB}$ & $86 \%$ & & & {$[15]$} \\
\hline SB & $88 \%$ & $\begin{array}{l}\text { Intensity of training [OR } 6.71 \text { ]; horses in } \\
\text { their first } 5 \text { months of training with the } \\
\text { highest risk at } 3 \text { months [OR 6.I7] }\end{array}$ & $\begin{array}{l}\text { Small sample size }(n=48) \text {; limited } \\
\text { to } 3 \text { training yards }\end{array}$ & [20] \\
\hline SB & $70 \%$ & $\begin{array}{l}\text { Horses that have raced in the last month } \\
\text { [OR 14.7] }\end{array}$ & & [40] \\
\hline TB, SB & $88 \%$ & $\begin{array}{l}\text { Horses } \geq 3 \text { years old; no difference in } \\
\text { prevalence between horses stabled full time, } \\
\text { kept at pasture for part of the day or kept at } \\
\text { pasture full time }\end{array}$ & & [60] \\
\hline TB & $72 \%$ & $\begin{array}{l}\text { Horses with stereotypies [OR } 5 \text { ]; time in } \\
\text { work } \leq 6 \text { weeks [OR } 0.3 \text { ]; aggression } \\
\text { towards to humans [OR } 0.12 \text { ] }\end{array}$ & & [37] \\
\hline \multicolumn{5}{|l|}{ Endurance horses } \\
\hline Arab, other & $57 \%$ & $\begin{array}{l}\text { Age; final ride position; days a week trained; } \\
\text { hours a day trained }\end{array}$ & Small sample size $(n=37)$ & [6।] \\
\hline Arab, Anglo-Arab & $\begin{array}{l}48-93 \% \\
\text { Prevalence } 48 \% \text { during } \\
\text { the inter-season period } \\
\text { and } 93 \% \text { during the } \\
\text { competition season }\end{array}$ & $\begin{array}{l}\text { Longer endurance race distance; high starch } \\
\text { diet }\end{array}$ & Small sample size $(n=30)$ & [42] \\
\hline \multicolumn{5}{|c|}{ Non-racing performance horses } \\
\hline Mixed breeds & $58 \%$ & $\begin{array}{l}\text { Active competition; nervous disposition; } \\
\text { lower RBC counts and hemoglobin } \\
\text { concentration }\end{array}$ & Small sample size $(n=50)$ & [62] \\
\hline $\begin{array}{l}\mathrm{QH} \\
\text { Western performance }\end{array}$ & $40 \%$ & & & [63] \\
\hline
\end{tabular}


Table I (Continued).

\begin{tabular}{|c|c|c|c|c|}
\hline Population & Prevalence & Risk Factors & Limitations & Ref. \\
\hline $\begin{array}{l}\text { Mixed breeds } \\
\text { Dressage, show jumping, } \\
\text { western performance, } \\
\text { endurance }\end{array}$ & $\begin{array}{l}17-56 \% \\
\text { Prevalence } 17 \% \text { before } \\
\text { competition season and } \\
56 \% \text { after competition } \\
\text { season }\end{array}$ & Active competition & & [43] \\
\hline $\begin{array}{l}\text { WB } \\
\text { Show jumpers }\end{array}$ & $25 \%$ & Increased exercise intensity [OR 3.8 ] & $\begin{array}{l}\text { Small sample size }(n=83) \text {; limited } \\
\text { to a small geographical radius }\end{array}$ & [38] \\
\hline $\begin{array}{l}\text { TB, other } \\
\text { Polo ponies }\end{array}$ & $37 \%$ & Decreasing exercise duration [OR 19.5] & Small sample size $(n=63)$ & {$[64]$} \\
\hline \multicolumn{5}{|c|}{ Non-performance horses } \\
\hline American paint horses & Experimental study & Transport and stall confinement & & {$[47]$} \\
\hline Mixed breeds & Experimental study & Repeated administration of oral electrolytes & & {$[48]$} \\
\hline $\begin{array}{l}\text { Mixed breeds } \\
\text { Riding school }\end{array}$ & $11 \%$ & Horses aged $2-6$ or $18-23$ years old & $\begin{array}{l}\text { Small sample size }(n=80) \text {; limited } \\
\text { to one riding centre }\end{array}$ & [65] \\
\hline $\begin{array}{l}\text { TB } \\
\text { Broodmares }\end{array}$ & $\begin{array}{l}67-76 \% \\
\text { Prevalence } 67 \% \text { in } \\
\text { pregnant mares and } 76 \% \\
\text { in non-pregnant mares }\end{array}$ & & $\begin{array}{l}\text { Small sample size }(n=62) \text {; limited } \\
\text { to one breeding farm }\end{array}$ & {$[66]$} \\
\hline $\begin{array}{l}\text { Mixed breeds } \\
\text { Pleasure horses }\end{array}$ & $53 \%$ & $\begin{array}{l}\text { Straw only available forage [OR } 4.2] \text {; } \geq \mathrm{I} g / \\
\mathrm{kg} \text { BW of starch per meal [OR } 2.6] \text {; water } \\
\text { not available in the turnout paddock [OR } \\
2.3 \text { ]; interval between forage feeding }>6 \\
\text { h [OR 5.3] }\end{array}$ & & $\begin{array}{r}{[19,} \\
46]\end{array}$ \\
\hline $\begin{array}{l}\text { Mixed breeds } \\
\text { Pleasure horses }\end{array}$ & $\begin{array}{l}48-66 \\
\text { Prevalence } 66 \% \text { in } \\
\text { symptomatic horses and } \\
48 \% \text { in asymptomatic } \\
\text { horses }\end{array}$ & & & [67] \\
\hline \multicolumn{5}{|l|}{ Donkeys and wild equids } \\
\hline Donkeys & $38 \%$ & & Small sample size $(n=39)$ & {$[68]$} \\
\hline Zebras in captivity & $64 \%$ & & $\begin{array}{l}\text { Small sample size }(n=55) \\
\text { postmortem study - prevalence } \\
\text { may have been influenced by } \\
\text { concomitant disease }\end{array}$ & [69] \\
\hline Feral horses & $\begin{array}{l}22 \% \\
\text { Prevalence } 61 \% \text { in } \\
\text { domestic horses and } 22 \% \\
\text { in feral horses }\end{array}$ & & $\begin{array}{l}\text { Abattoir study - prevalence may } \\
\text { have been influenced by } \\
\text { transport and fasting }\end{array}$ & [56] \\
\hline \multicolumn{5}{|l|}{ Foals } \\
\hline $\begin{array}{l}\text { TB foals } \\
2-85 \text { days old }\end{array}$ & $\begin{array}{l}47-57 \% \\
\text { Prevalence } 47 \% \text { in Ireland } \\
\text { and } 57 \% \text { in England }\end{array}$ & & & [70] \\
\hline
\end{tabular}


Table I (Continued).

\begin{tabular}{|l|l|l|l|l|}
\hline Population & Prevalence & Risk Factors & Limitations & Ref. \\
\hline $\begin{array}{l}\text { WB foals } \\
82-200 \text { days old }\end{array}$ & $\begin{array}{l}7-97 \% \\
\text { Prevalence 7\% before } \\
\text { weaning and 97\% after } \\
\text { weaning }\end{array}$ & & Limited to one breeding farm & [18] \\
\hline $\begin{array}{l}\text { Mixed breeds } \\
\text { I-180 days old }\end{array}$ & $\begin{array}{l}17 \% \\
\text { Prevalence lowest in } \\
\text { neonatal foals }\end{array}$ & $\begin{array}{l}\text { Foals > I month old; } \\
\text { concomitant gastrointestinal disease }\end{array}$ & $\begin{array}{l}\text { Postmortem study - prevalence } \\
\text { may have been influenced by } \\
\text { concomitant disease }\end{array}$ & [58] \\
\hline
\end{tabular}

Note: Colors denotes different subpopulations of horses.

Abbreviations: OR, odds ratio; QH, Quarter horse; SB, Standardbred; TB, Thoroughbred; WB, Warmblood.

Non-performance horses are also susceptible to ESGD however the prevalence is generally lower, and when lesions occur, they tend to be less severe. This suggests that risk factors other than intense exercise and management may play a role and underscores the multifactorial nature of this disease. There is conflicting evidence for the role that intrinsic risk factors, such as age, gender and breed, may play a role in the development of ESGD and where evidence exists, it is likely to be confounded by other factors such as management and exercise. Feeding of straw has been associated with an increased risk of ESGD, presumably due to the abrasive effect of the coarse roughage, and this may be relevant to other forage with a high lignin content. ${ }^{46}$ Stress and administration of inappropriate doses of non-steroidal anti-inflammatory drugs (NSAIDs) have been associated with an increased risk of EGGD; however, there is currently no conclusive evidence to suggest that a similar association exists with ESGD. ${ }^{53-55}$

Interestingly, ESGD has also been reported in wild equids and feral horses with no apparent exposure to recognized risk factors, and it poses an interesting (and as yet unanswered) question as to whether some degree of ESGD is "constitutive" in the equine stomach and develops as a normal response to periodic exposure of the squamous mucosa to acid. ${ }^{56}$ This notion is supported by the fact that many horses with ESGD will not demonstrate clinical signs and the fact that mild lesions may heal spontaneously, particularly if the inciting cause has been removed. 3,57

In foals, the prevalence of ESGD ranges from $7 \%$ to $57 \%$ depending upon the age. Older weanling foals appear to be most susceptible, however ESGD has also been reported in foals as young as 24 hours. ${ }^{58}$ Very few risk factors have been reported for ESGD in foals.
Concomitant gastrointestinal disease has been associated with the presence of ESGD at the time of necropsy, however a cause-and-effect relationship has not been demonstrated. ${ }^{58}$

\section{Clinical Signs}

Numerous clinical signs have been attributed to ESGD in adult horses and foals, however there is currently very little evidence to support a direct association between any of these signs and the presence or absence of lesions seen on gastroscopy. The evidence that is available is often conflicting and therefore establishing the clinical significance of ESGD can be challenging. ${ }^{1}$ Most of the clinical signs are non-specific and are often subjective and owner perceived. This is complicated further by the fact that horses with ESGD may not demonstrate clinical signs and if they do, the signs do not necessarily correlate with the severity of the lesions seen on gastroscopy. ${ }^{16,41,54,70} \mathrm{In}$ addition, horses will often present with ESGD and EGGD concurrently; and to date there has been no attempt to differentiate between EGGD and ESGD when reporting clinical symptomatology. Clinical signs suggestive of ESGD should therefore always be interpreted in context, and gastroscopy should always be performed to confirm the disease.

Clinical signs that have been attributed to ESGD in adult horses include inappetence, poor body condition or weight loss, changes in behavior, acute or recurrent colic, bruxism, and stereotypic behavior (crib biting, stall weaving) and poor performance. ${ }^{1}$ In light of the disproportionately high prevalence of ESGD in performance horses, poor performance has perhaps received the most attention, yet surprisingly, there are very few studies that have investigated the relationship between poor performance 
and ESGD. ${ }^{54,71,72}$ This may be in part due to the difficulties in excluding the many confounding factors that might influence poor performance, including the effects of ESGD on appetite and interruption of training. ${ }^{1}$ The exact mechanism by which ESGD may affect performance has not been elucidated but is likely to be related to epigastric pain. ${ }^{73}$ In people, epigastric pain is defined as pain localized to an area below the sternum and above the umbilicus and is common in athletes with GERD. ${ }^{74}$ Acid reflux onto the sensitive squamous epithelium of the esophagus during exercise causes a "burning sensation" that is proportional to increasing exercise intensity and has been shown to affect performance. ${ }^{75}$ Horses with ESGD have similar lesions to those causing GERD in human athletes, and the problem is likely to be compounded by the fact that the squamous epithelium extends into the proximal one-third of the stomach and is not protected by an esophageal sphincter. Interestingly, a recent study in human athletes suggested that GERD may be associated with increased abdominal pressure during exercise, a mechanism that is all too familiar in the equine athlete. $^{44,76}$ The exact mechanism by which epigastric pain impacts on athletic performance in the horse is a matter of ongoing speculation. One theory is that it may affect stride length, leading to reduced time to fatigue and a lower increase in maximal specific oxygen uptake during peak exercise. ${ }^{72}$

The clinical signs of ESGD in foals have traditionally been divided into four distinct syndromes, however this classification is historical and should no longer be used. ${ }^{24}$ Foals and adults share the same underlying pathogenesis and differences in the spectrum of clinical disease in foals can be attributed to differences in diet, behavior and duration and severity of ulceration. As is the case in adult horses, foals will often be asymptomatic. ${ }^{18,70}$ When clinical signs do occur, they tend to manifest as poor body condition, inappetence, ptyalism, bruxism or colic. ${ }^{24}$ Perhaps, the most important difference in clinical symptomatology between foals and adult horses is that foals are more likely to develop severe disease and this may result in full thickness perforation which is invariably fatal. ${ }^{24}$ Foals are also more likely to develop chronic secondary ESGD as a consequence of gastric outflow obstruction. ${ }^{34}$ This may arise from cardiac, antral, pyloric or proximal duodenal strictures, although strictures involving the proximal duodenum appear to be more common than those involving the stomach. ${ }^{24}$

\section{Diagnosis}

At present, the only reliable antemortem test for ESGD is gastroscopy. Other methods such as blood biomarkers have been investigated with variable results. Serum amyloid A concentration was not associated with the presence of ESGD, and no significant correlation was found between fecal albumin and hemoglobin values and gastric ulcer score. ${ }^{77,78}$ Blood sucrose concentration was shown to have poor sensitivity and specificity for the diagnosis of gastric ulceration in adult horses. ${ }^{79}$ The test was shown to have better sensitivity in weanling foals, but specificity remained poor, limiting its use in a screening test to identify foals that may benefit from gastroscopy. ${ }^{18}$ Hair cortisol concentrations were lower in horses with ESGD and were negatively correlated with lesion severity, but further work is needed to explore this association. ${ }^{80}$ More recently, proteomic analysis has identified several candidate proteins associated with the presence of ESGD. However, these proteins are not well characterized in the horse and further work is needed to understand their function and relationship to ESGD. ${ }^{81}$ Owner questionnaires have also been investigated as a diagnostic tool. ${ }^{36,82}$ A recent study found that a questionnaire was not useful for predicting the presence and the severity of lesions detected during gastroscopic examination. ${ }^{36}$ However, answers to some of the questions did correlate with the development of gastric lesions. Such questionnaires may be a useful tool to evaluate the risk of ESGD but cannot replace gastroscopic examination to make a definitive diagnosis.

Gastroscopy requires some degree of expertise and specialized equipment; a three-meter videoendoscope is necessary to reach the stomach of an adult horse and visualise the squamous mucosa. Complications associated with the procedure include small intestinal segmental volvulus, which was documented on four horses following gastroscopy. ${ }^{83}$ A larger study reported colic signs in $0.9 \%$ of healthy horses undergoing routine gastroscopy. ${ }^{84}$ Although insufflation of air has not been shown to increase the odds of colic, it appears prudent to deflate the stomach following the procedure.

Multiple scoring systems for ESGD have been described including a number/severity system, ${ }^{85}$ a $0-3$ ordinal system, ${ }^{39,51,86}$ and a system based on lesion depth and surface area. A 0-4 scoring system was recommended by the Equine Gastric Ulcer Council in 1999. ${ }^{2}$ This was subsequently shown to perform better than the 
number/severity scoring system and remains widely used, both in clinical practice and in research settings ${ }^{87}$ The $0-4$ grading system was recently shown to have substantial inter- and intra-observer agreement (0.69 and 0.80, respectively) and appears to perform well regardless of observer experience. ${ }^{88}$ The same study investigated the use of a visual analog scale, in order to generate continuous data over a 100-point scale based on the severity of ulceration. This had moderate interobserver and intra-observer agreement, which improved with experience, but was found to be inferior to the $0-4$ scoring system for ESGD. Endoscopic assessment is subjective to some extent and may under- or overestimate the severity or depth of squamous lesions. ${ }^{89}$ Unlike the glandular mucosa, where a range of lesion types are documented, biopsy is rarely indicated for squamous lesions, which tend to be more homogenous in appearance, and represent true ulceration rather than an inflammatory process. ${ }^{3,23}$ However, biopsy remains the only available method to accurately determine lesion depth.

Because there is currently little evidence to suggest an association between lesion severity and clinical signs, determining the clinical significance of lesions seen on gastroscopy can be difficult. Lesions are therefore typically considered to be clinically significant once there is a breach of the squamous epithelium, ie, $\geq$ grade $2 / 4$. The clinical significance of hyperkeratosis (grade 1/4) remains unclear; however, it may represent an early manifestation of acid injury, and there are anecdotal reports of horses with hyperkeratosis responding to treatment. ${ }^{1,23}$

In the absence of gastroscopy, it is possible to commence treatment and assess clinical response, bearing in mind that clinical signs are numerous and variable, this approach can be costly, and gastroscopy is still necessary to conclusively rule out ESGD if clinical improvement is not seen with treatment.

\section{Treatment and Management}

It is now well established that acid is directly implicated in the development of ESGD and therefore treatment should be aimed at acid suppression. Spontaneous healing of ESGD is variable, with reported healing rates of less than $5 \%$ in horses in training and up to $55 \%$ in horses at pasture. ${ }^{57,86,90}$ Treatment is therefore recommended for any horse with a clear disruption of squamous epithelial integrity, ie, $\geq$ grade 2 . It is important to remember, however, that acid suppression does not initiate healing, but rather, it facilitates healing by providing an optimal environment for healing to occur. ${ }^{3}$ Treatment should therefore always be done in conjunction with appropriate management changes that mitigate against reoccurrence of disease. The efficacy of acid suppressants for the treatment of ESGD can be assessed by demonstrating an increase in $\mathrm{pH}$ in the stomach and an improvement in lesion score. In people, it is recommended that the intra-day percentage of time that gastric $\mathrm{pH}$ is maintained above 4 should be greater than $66 \%$ to facilitate healing,,${ }^{91,92}$ and similar criteria have been used for horses. ${ }^{93,94}$

\section{Proton Pump Inhibitors (PPIs) Omeprazole}

The drug of choice for acid suppression in the horse is omeprazole. It irreversibly inhibits the $\mathrm{H}+/ \mathrm{K}+$ ATPase pump on the secretory surface of the gastric parietal cell, taking up to five days to reach steady state concentration. ${ }^{86,95}$ Various formulations of oral omeprazole are available, including plain paste, buffered paste or enteric coated preparations. The oral bioavailability of plain omeprazole paste is approximately $10 \%$ in the fasted state. ${ }^{96}$ Enteric coated formulations have higher bioavailability (median 22\%), although considerable inter-horse variation appears to exist ${ }^{26}$ and plasma concentrations of omeprazole do not appear to predict drug pharmacodynamics in horses. ${ }^{94,96}$

The duration of acid suppression required over a 24hour period to allow healing of lesions is currently unknown. Doses ranging from $0.5-4 \mathrm{mg} / \mathrm{kg}$ have been reported (Table 2). A recent study demonstrated that dose does not appear to predict pharmacodynamics of omeprazole, suggesting that lower dose rates $(1 \mathrm{mg} / \mathrm{kg})$ may be as effective as higher doses. ${ }^{94}$ Administration in the fasted state appears to be an important factor, improving the area under the curve by $300 \%$ in one study, ${ }^{97}$ although this difference was not repeatable in subsequent work. ${ }^{96}$ Horses on an ad libitum hay were shown to require higher doses of omeprazole to achieve sufficient acid suppression in one study. ${ }^{95}$ When oral omeprazole is administered prior to feeding and before exercise, doses as low as $1 \mathrm{mg} / \mathrm{kg}$ bwt may be as effective as higher doses. ${ }^{98}$ It is worth noting that this study used an enteric coated preparation. Lower dose rates have not been investigated with buffered or plain formulations, although another study comparing three commercially available buffered pastes and two enteric coated granule preparations found that the method of protection utilized did not significantly alter the pharmacokinetics of the drug. ${ }^{99}$ 
Table 2 Reported Dose Rates for Oral Omeprazole for the Treatment or Prophylaxis of ESGD

\begin{tabular}{|c|c|c|c|c|c|}
\hline Dose & Formula & Population & Outcome & Limitations & Ref. \\
\hline I mg/kg bwt & $\begin{array}{l}\text { Gastrogard } \\
\text { Buffered paste }\end{array}$ & $\begin{array}{l}6 \text { TB horses } \\
\text { Experimental }\end{array}$ & $\begin{array}{l}\text { Increased gastric } \mathrm{pH} \\
\text { Better on low hay diet }\end{array}$ & $\begin{array}{l}\text { Experimental study; small number of horses; outcome measured by change in } \mathrm{pH} \text { not effect on } \\
\text { ulceration }\end{array}$ & [95] \\
\hline $4 \mathrm{mg} / \mathrm{kg}$ bwt & $\begin{array}{l}\text { Gastrogard }^{\circledR} \\
\text { Buffered paste }\end{array}$ & $\begin{array}{l}6 \text { TB horses } \\
\text { Experimental }\end{array}$ & $\begin{array}{l}\text { Increased gastric } \mathrm{pH} \\
\text { Better on low hay diet }\end{array}$ & $\begin{array}{l}\text { Experimental study; small number of horses; outcome measured by change in } \mathrm{pH} \text { not effect on } \\
\text { ulceration }\end{array}$ & [95] \\
\hline $4 \mathrm{mg} / \mathrm{kg}$ bwt & $\begin{array}{l}\text { Gastrogard }{ }^{\circledR} \\
\text { Buffered paste }\end{array}$ & $\begin{array}{l}140 \text { horses and } \\
\text { foals }\end{array}$ & $\begin{array}{l}\text { Improved: } 99 \% \\
\text { Healed: } 87 \%\end{array}$ & $\begin{array}{l}\text { Only re-evaluated at } 28 \text { days so response to treatment could have occurred sooner; mixed } \\
\text { population; some administration intermittent with racehorse withdrawal times }\end{array}$ & [102] \\
\hline $\begin{array}{l}\text { I mg/kg bwt } \\
\text { Pre-exercise }\end{array}$ & $\begin{array}{l}\text { Gastrozol }^{\circledR} \\
\text { Enteric coated paste }\end{array}$ & $\begin{array}{l}18 \mathrm{~TB} \\
\text { racehorses }\end{array}$ & $\begin{array}{l}\text { Improved: } 100 \% \\
\text { Healed: } 89 \%\end{array}$ & $\begin{array}{l}\text { Exact period of fasting before medication administered unknown; cannot extrapolate to buffered } \\
\text { or plain paste; small number of horses }\end{array}$ & [98] \\
\hline $\begin{array}{l}2 \mathrm{mg} / \mathrm{kg} \text { bwt } \\
\text { Pre-exercise }\end{array}$ & $\begin{array}{l}\text { Gastrozol }^{\circledR} \\
\text { Enteric coated paste }\end{array}$ & $\begin{array}{l}16 \mathrm{~TB} \\
\text { racehorses }\end{array}$ & $\begin{array}{l}\text { Improved: } 100 \% \\
\text { Healed: } 94 \%\end{array}$ & $\begin{array}{l}\text { Exact period of fasting before medication administered unknown; cannot extrapolate to buffered } \\
\text { or plain paste; small number of horses }\end{array}$ & [98] \\
\hline $\begin{array}{l}4 \mathrm{mg} / \mathrm{kg} \text { bwt } \\
\text { Pre-exercise }\end{array}$ & $\begin{array}{l}\text { Gastrozol }^{\circledR} \\
\text { Enteric coated paste }\end{array}$ & $\begin{array}{l}16 \mathrm{~TB} \\
\text { racehorses }\end{array}$ & $\begin{array}{l}\text { Improved: } 88 \% \\
\text { Healed: } 75 \%\end{array}$ & $\begin{array}{l}\text { Exact period of fasting before medication administered unknown; cannot extrapolate to buffered } \\
\text { or plain paste; small number of horses }\end{array}$ & [98] \\
\hline $\begin{array}{l}4 \mathrm{mg} / \mathrm{kg} \text { bwt } \\
\text { Pre-exercise }\end{array}$ & $\begin{array}{l}\text { Abgard }^{\circledR} \\
\text { Buffered paste }\end{array}$ & $\begin{array}{l}13 \mathrm{~TB} \text { race } \\
\text { horses in } \\
\text { training }\end{array}$ & $\begin{array}{l}\text { Improved: } 100 \% \\
\text { Healed: } 92 \%\end{array}$ & Small number of horses & {$[107]$} \\
\hline $\begin{array}{l}4 \mathrm{mg} / \mathrm{kg} \text { bwt } \\
\text { Post-exercise }\end{array}$ & $\begin{array}{l}\text { Abgard }^{\circledR} \\
\text { Buffered paste }\end{array}$ & $\begin{array}{l}12 \mathrm{~TB} \\
\text { racehorses in } \\
\text { training }\end{array}$ & $\begin{array}{l}\text { Improved: } 92 \% \\
\text { Healed: } 67 \%\end{array}$ & Small number of horses & [107] \\
\hline $4 \mathrm{mg} / \mathrm{kg}$ bwt & $\begin{array}{l}\text { Peptizole }{ }^{\circledR} \text { Plain paste } \\
\text { OR } \\
\text { Gastrogard }{ }^{\circledR} \text { Buffered } \\
\text { paste }\end{array}$ & $\begin{array}{l}27 \text { mixed } \\
\text { breed horses }\end{array}$ & $\begin{array}{l}\text { Improved } 89 \% \\
\text { Healed } 67 \%\end{array}$ & Plain and buffered formulations combined into same category; management not standardized & {$[100]$} \\
\hline $0.5 \mathrm{mg} / \mathrm{kg}$ bwt & $\begin{array}{l}\text { Gastrozol }^{\circledR} \\
\text { Enteric coated paste }\end{array}$ & $\begin{array}{l}17 \mathrm{~TB} \\
\text { racehorses in } \\
\text { training }\end{array}$ & $\begin{array}{l}\text { Prophylaxis } \\
12 \% \text { worsened }\end{array}$ & $\begin{array}{l}\text { Small number of horses; limited to racehorse population; cannot extrapolate to buffered or plain } \\
\text { paste }\end{array}$ & [108] \\
\hline I mg/kg bwt & $\begin{array}{l}\text { Gastrozol }^{\circledR} \\
\text { Enteric coated paste }\end{array}$ & $\begin{array}{l}16 \mathrm{~TB} \\
\text { racehorses in } \\
\text { training }\end{array}$ & $\begin{array}{l}\text { Prophylaxis } \\
6 \% \text { worsened }\end{array}$ & $\begin{array}{l}\text { Small number of horses; limited to racehorse population; cannot extrapolate to buffered or plain } \\
\text { paste }\end{array}$ & {$[108]$} \\
\hline
\end{tabular}

Note: Colors denote different studies.

Abbreviations: bwt, body weight; TB, Thoroughbred. 
Rates of healing of ESGD following oral omeprazole treatment have been reported between $67 \%$ and 94\%. ${ }^{86,98,100-102}$ Differences in dose, diet, management, and duration of treatment between studies may contribute to this variability. The ECEIM consensus statement recommends three weeks of omeprazole treatment for ESGD, ${ }^{1}$ on the basis that most healing has occurred by day $21 .^{103}$ However, studies investigating this duration of omeprazole treatment for ESGD are lacking. Healing is generally defined as grade $<1 / 4$, indicating the integrity of the squamous mucosa, although care should be taken when comparing studies, as different definitions may be used. The requirement for withdrawal times may influence success rates with omeprazole treatment in racehorses. Kerbyson et al demonstrated ulcer healing (grade $<1 / 4$ ) in $52 \%$ of Thoroughbred racehorses following 4 weeks of treatment with $4 \mathrm{mg} / \mathrm{kg}$ buffered omeprazole paste where horses raced as normal, with five-day withdrawal periods observed prior to each race. ${ }^{104}$ This is lower than published figures following treatment with an uninterrupted course but may be more representative of use in clinical practice.

Administration of intravenous omeprazole has been described and has been shown to be effective in increasing gastric $\mathrm{pH} .{ }^{105}$ However, the short half-life and requirement for daily injections make this a less attractive option in practice. A compounded, long-acting intramuscular preparation has become available in recent years and has been shown to be highly effective for ESGD when used at a dose of $4 \mathrm{mg} / \mathrm{kg}$ every 5-7 days. ${ }^{106}$ A more recent study found that healing occurred in $97 \%$ of horses treated with the intramuscular preparation for four weeks, compared to $67 \%$ of those treated with an equivalent dose of oral omeprazole paste. ${ }^{100}$ Mild localized swelling was reported in $5 \%$ of the injections administered.

\section{Esomeprazole}

Esomeprazole, a second-generation proton pump inhibitor, is the $S$-isomer of omeprazole. In people, it is metabolized more slowly than omeprazole, resulting in a higher area under the concentration-time curve after administration of the same dose. ${ }^{109}$ It is superior to other proton pump inhibitors for the treatment of reflux esophagitis in people and has been shown to have less variation between patients. ${ }^{110,111}$ Evidence for the use of esomeprazole in the treatment of ESGD is currently limited. Intravenous administration for 14 days caused a significant increase in gastric $\mathrm{pH},{ }^{112}$ and a preliminary study found that oral doses of a licensed human preparation of esomeprazole magnesium (Nexium) as small as $40 \mathrm{mg}$ daily in Thoroughbred racehorses resulted in acid suppression when given for five days. ${ }^{113}$ More recent studies have showed that enteric coated oral esomeprazole (0.5$2.0 \mathrm{mg} / \mathrm{kg} \mathrm{q} 24 \mathrm{~h}$ ) increases gastric $\mathrm{pH}$ and was as effective as oral omeprazole at increasing gastric $\mathrm{pH} .{ }^{114,115}$ Diet appears to have an effect, with horses on a hay only diet requiring a higher dose $(2 \mathrm{mg} / \mathrm{kg}$ q24h) to achieve acid suppression compared to those on a concentrate-based diet. ${ }^{114}$ Further studies are needed to determine if esomeprazole carries any benefit compared to omeprazole in the horse. It was recently reported to result in resolution of lesions in horses that were refractory to omeprazole treatment, ${ }^{116}$ however the number of horses in the study was small, and larger comparative trials are needed. At present, there is no licensed product for use in the horse, however it may represent a useful "off-label" alternative for horses with ESGD that are refractory to omeprazole treatment. Intravenous pantoprazole caused a significant increase in the gastric $\mathrm{pH}$ of healthy foals, but use has not been described in adult horses and is likely to be costprohibitive. $^{117}$

\section{Side Effects of PPIs}

Long-term omeprazole use can cause interstitial nephritis in people, thought to be related to induction of oxidative stress and renal tubular cell death. ${ }^{118}$ At present, there is no published work examining the potential renal side effects in the horse. Omeprazole did not induce significant major changes in the composition of fecal or gastric glandular microbiota in horses, suggesting it may have fewer effects on the gastrointestinal microbiome compared to other species. It is worth noting, however, that the duration of omeprazole treatment in the horse tends to be significantly shorter than in people, where PPI treatment may continue for decades.

Proton pump inhibitors have also been linked to reduced nutrient digestibility in people. ${ }^{119}$ In horses, reduced calcium digestibility following omeprazole administration has been demonstrated. This is likely due to an increase in gastric fluid $\mathrm{pH}$ causing a reduction in calcium solubility and subsequent digestibility. ${ }^{120}$ This is unlikely to be clinically significant in horses on a diet with normal calcium intake but should be borne in mind. Conversely, another study found that short-term administration (60 days) of oral omeprazole did not significantly affect total and ionized serum calcium concentrations in 
healthy horses. ${ }^{121}$ Bone density and bone mineral content were also not affected.

The loss of negative feedback from gastric acid during PPI treatment causes an increase in gastrin secretion. In some people, hypergastrinemia has a positive trophic effect on the gastric mucosa and has been linked to the development of gastric carcinoids. ${ }^{122}$ Octreotide acetate, a somatostatin analogue, inhibits gastrin secretion and has been shown to increase the gastric $\mathrm{pH}$ in horses, ${ }^{123}$ but this benefit is unclear, as gastric hypertrophy following prolonged use of PPIs has not been reported in the horse to date.

ESGD may recur following discontinuation of treatment with omeprazole ${ }^{86}$ and rebound acid secretion may be implicated. This phenomenon occurs in people following the discontinuation of PPIs and is again linked to an increase in gastrin that can persist for up to 14 days. ${ }^{124}$ Furthermore, enterochromaffin-like (ECL) cells, which release histamine signaling for gastric acid production, proliferate due to the trophic effects of hypergastrinemia. Together, these factors are responsible for increased gastric acid production when treatment is stopped. Whilst there is currently no direct evidence to suggest that rebound acid secretion occurs in horses, it has been shown that treatment with oral omeprazole results in hypergastrinemia, and further studies are needed to determine the implications of this on acid production following discontinuation of treatment. ${ }^{120}$ Despite the current lack of evidence, many practitioners will taper the dose of omeprazole due to concerns over rebound acid secretion. Unfortunately, there are also no studies that have compared the effect of sudden discontinuation of treatment with a tapering dose on the reoccurrence of ESGD, and therefore it is difficult to determine if there is any benefit to this practice. Other factors may also play a role in recurrence of ESGD, particularly in performance horses that continue to race, and therefore the practice of prophylactic (maintenance) treatment with omeprazole is also common. There is some evidence to suggest that this may have a benefit, as it has been shown in a recent meta-analysis, that prophylactic treatment with $1 \mathrm{mg} / \mathrm{kg}$ or $2 \mathrm{mg} / \mathrm{kg}$ PO SID of oral omeprazole paste is superior to a sham treatment for preventing recurrence of ESGD. ${ }^{125}$ Furthermore, another study found that doses as low as $0.5 \mathrm{mg} / \mathrm{kg}$ of enteric coated paste prevented development of ESGD in racehorses in training and did not differ in effect from a $1 \mathrm{mg} / \mathrm{kg}$ dose (Table 2). ${ }^{108}$

\section{H2 Receptor Antagonists}

$\mathrm{H} 2$ receptor antagonists (H2RA) prevent histamine from binding to its receptor on the gastric parietal cell, suppressing acid production. Ranitidine increased the gastric fluid $\mathrm{pH}>6$ for a longer duration than did famotidine in one study. ${ }^{126}$ Limited acid secretion may continue in the face of H2RA treatment, and ranitidine has been shown to be inferior to omeprazole in adult horses for treatment of ESGD. ${ }^{127}$ Another study found cimetidine $(20 \mathrm{mg} / \mathrm{kg}$ PO q8h) to be less effective than omeprazole for treating ESGD in Thoroughbred racehorses in training. ${ }^{128}$ The requirement for more frequent dosing also makes this class of drug a less appealing option in clinical practice. At present, there is no licensed equine product.

\section{Potassium-Competitive Acid Blockers}

In some people, potassium-competitive acid blockers (PCABS) such as vonoprazan and revaprazan provide an attractive alternative to proton pump inhibitors. This class of drug binds reversibly to the potassium-binding site of the $\mathrm{H}+/ \mathrm{K}+$ ATPase and accumulates at a higher concentration in the parietal cell than PPIs. Other benefits include a long half-life, efficacy from the first dose, and the ability to administer the drug regardless of fed or fasted state. ${ }^{129}$ PCABs have also been effective at treating PPI refractory GERD in people. ${ }^{130}$ At present, there are no published studies examining the use of PCABs in horses.

\section{Supplements}

Numerous supplements are marketed for ESGD, often with limited evidence to support their use in the horse. Demonstrating the benefits of a particular supplement can be difficult as the effect may be too weak to detect in a clinical trial and reported benefits may be influenced by owner perception. ${ }^{131}$

Antacids are commonly included in commercial gastric supplements and act by buffering gastric acid. A combination of aluminium hydroxide and magnesium hydroxide increased gastric $\mathrm{pH}$ for up to two hours after oral administration; however, the need for such frequent dosing makes this a less practical option for prolonged acid suppression. ${ }^{132}$ Pectin, a gel-forming carbohydrate polymer and lecithin, an amphiphilic phospholipid, have received a good deal of attention due to their suggested ability to form a protective gel barrier within the stomach. ${ }^{133}$ Their evidence for use in ESGD appears to be contradictory. Early studies showed that a pectin- 
lecithin-glycerol complex $\left(\right.$ Apolectol ${ }^{\circledR}$ ) had a beneficial effect on the healing of gastric ulcers, with horses receiving this complex showing improvement or resolution of ulceration compared to controls. ${ }^{134}$ However, other work has found that pectin-lecithin complex failed to prevent lesions in the squamous mucosa induced by intermittent feed deprivation. ${ }^{133,135}$ More recent work demonstrated that a combination of Apolectol ${ }^{\circledR}$, live yeast and magnesium hydroxide was an effective prophylactic against ESGD. ${ }^{136}$

A supplement containing beta glucan, saccharomyces yeast and amino acids (Succeed digestive conditioning ${ }^{\circledR}$ ) was inferior to omeprazole when compared over a 30-day period in racehorses in training but when examined over a 90-day period, was found to be non-inferior to omeprazole. ${ }^{104} \mathrm{~A}$ similar supplement containing herbs, polysaccharides, amino acids, antioxidants and probiotics (Smart Gut Ultra Pellet ${ }^{\circledR}$ ) prevented the number of squamous ulcers from increasing in intermittently fed stabled horses following omeprazole treatment when compared to untreated controls. ${ }^{78}$ Porcine hydrolyzed collagen enhanced the effects of omeprazole on gastric $\mathrm{pH}$, inhibited gastrin secretion after feeding and resulted in fewer squamous ulcers after long term (56 days) in stall-confined horses undergoing omeprazole treatment and feeddeprivation. ${ }^{137}$

Some studies have demonstrated a lack of efficacy of commonly used supplements. A supplement containing sea buckthorn liquid fed to horses did not show efficacy in the treatment or prevention of naturally occurring ESGD in horses. ${ }^{138}$ Aloe vera was shown to be inferior to omeprazole for the treatment of ESGD, ${ }^{139}$ and a Chinese herbal supplement blend (Wei le San) was no more effective than a placebo. ${ }^{140}$

\section{Dietary Modifications}

The risk of developing ESGD increased when straw was the only forage available, $1 \mathrm{~g} / \mathrm{kg}$ bwt of starch per meal was exceeded, water was not available in the turnout paddock, and the interval between forage feeding was $<6 \mathrm{~h}^{46} \mathrm{~A}$ high fibre, low-starch diet had a positive outcome on gastric and fecal microbiota and promoted gastric ulcer healing in one study. ${ }^{141}$ Horses with ulcers were shown to have less microbiota diversity than those without and improvement in ulcer scores was associated with an increase in specific carbohydrate-utilising species and a decrease in lactate- fermenting species. Recent work showed that dietary modification played a significant role following discontinuation of omeprazole therapy in horses with ESGD. ${ }^{142}$ Horses that were maintained on a high fibre, oil based, low starch concentrate feed remained unchanged following discontinuation of omeprazole therapy, while those that did not undergo dietary modification regressed following discontinuation of omeprazole therapy, to the point where ulcer scores did not differ from the start of treatment.

The addition of oil is commonly recommended as part of treatment for ESGD, although there is limited published evidence to support its use. Supplementation with $240 \mathrm{~mL}$ of corn oil, refined rice bran oil, or crude rice bran oil ( 0.5 to $0.6 \mathrm{~mL} / \mathrm{kg} \mathrm{bwt}$ ) did not significantly alter the development of gastric ulcers in a feed deprivation model. ${ }^{143}$ In a smaller study of four ponies, $45 \mathrm{~mL}$ of corn oil fed daily for five weeks caused decreased acid output and increased PGE2 and sodium output compared to those measured before corn oil supplementation, although gastroscopy was not used to assess the gastric mucosa. ${ }^{144} \mathrm{~A}$ more recent study found that corn oil did not have any effect on healing in the squamous mucosa following phenylbutazone-induced ulceration. ${ }^{145}$ The addition of oil may be useful in replacing calories when transitioning away from a high starch diet.

Regular feeding of concentrates using a commercially automated feeder resulted in fewer ulcer scores compared to traditional feeding, ${ }^{146}$ although this involved splitting the feed into 20 aliquots over a 24-hour period, which is difficult to replicate in a practical setting. Feeding a small amount of chaff prior to exercise is commonly recommended to reduce acid splashing in the stomach, although there are no published studies investigating the effects of this.

\section{Conclusion}

Although ESGD is a common condition in the adult horse, interpretation of prevalence studies is complicated by several factors, making estimation of true prevalence challenging. The clinical significance of mild lesions remains unclear, raising the question as to whether these mild lesions represent a normal response to periodic exposure of the squamous mucosa to acid. It is difficult to define the full extent of the impact of ESGD on the equine industry, partly due to the variable nature of clinical signs and their lack of association with the presence of lesions and partly due to the inherent challenges associated with investigating poor performance in the equine athlete. Recent developments in the management 
of ESGD include a long-acting intramuscular omeprazole preparation, with promising results. Evidence for the use of dietary supplements remains limited, but potassiumcompetitive acid blockers may represent an alternative to proton pump inhibitors in the future.

\section{Disclosure}

The authors report no conflicts of interest in this work.

\section{References}

1. Sykes BW, Hewetson M, Hepburn RJ, Luthersson N, Tamzali Y. European College of Equine Internal Medicine consensus statement-equine gastric ulcer syndrome in adult horses. $J$ Vet Intern Med. 2015;29(5):1288-1299. doi:10.1111/jvim.13578

2. Andrews FM, Bernard WV, Byars TD, et al. Recommendations for the diagnosis and treatment of equine gastric ulcer syndrome (EGUS). Equine Vet Educ. 1999;1:122-134. doi:10.1111/j.20423292.1999.tb00961.x

3. Murray MJ, Eichorn ES, Jeffrey SC. Histological characteristics of induced acute peptic injury in equine gastric squamous epithelium. Equine Vet J. 2001;33(6):554-560. doi:10.2746/ 042516401776563517

4. Campbell-Thompson ML, Merritt AM. Effect of ranitidine on gastric acid secretion in young male horses. Am J Vet Res. 1987;48(10):1511-1515.

5. Husted L, Sanchez LC, Olsen SN, Baptiste KE, Merritt AM. Effect of paddock vs. stall housing on 24 hour gastric $\mathrm{pH}$ within the proximal and ventral equine stomach. Equine Vet J. 2008;40 (4):337-341. doi:10.2746/042516408x284673

6. Ellis A, Upton S, Zinchenko S, et al. The effect of presenting forage in multi-layered haynets and at multiple sites on night time budgets of stabled horses. Appl Anim Behav Sci. 2015;171:108-116. doi:10.1016/j.applanim.2015.08.012

7. Argenzio RA. Comparative pathophysiology of nonglandular ulcer disease: a review of experimental studies. Equine Vet J Suppl. 1999;29:19-23. doi:10.1111/j.2042-3306.1999.tb05163.x

8. Andrews FM, Buchanan BR, Smith SH, Elliott SB, Saxton AM. In vitro effects of hydrochloric acid and various concentrations of acetic, propionic, butyric, or valeric acids on bioelectric properties of equine gastric squamous mucosa. Am J Vet Res. 2006;67 (11):1873-1882. doi:10.2460/ajvr.67.11.1873

9. Andrews FM, Buchanan BR, Elliott SB, et al. In vitro effects of hydrochloric and lactic acids on bioelectric properties of equine gastric squamous mucosa. Equine Vet J. 2008;40(4):301-305. doi: $10.2746 / 042516408 \times 293565$

10. Nadeau JA, Andrews FM, Patton CS, et al. Effects of hydrochloric, acetic, butyric, and propionic acids on pathogenesis of ulcers in the nonglandular portion of the stomach of horses. Am J Vet Res. 2003;64(4):404-412. doi:10.2460/ajvr.2003.64.404

11. Nadeau JA, Andrews FM, Patton CS, et al. Effects of hydrochloric, valeric, and other volatile fatty acids on pathogenesis of ulcers in the nonglandular portion of the stomach of horses. Am J Vet Res. 2003;64(4):413-417. doi:10.2460/ajvr.2003.64.413

12. Berschneider HM, Blikslager AT, Roberts MC. Role of duodenal reflux in nonglandular gastric ulcer disease of the mature horse. Equine Vet J Suppl. 1999;29:24-29. doi:10.1111/j.20423306.1999.tb05164.x

13. Wise JC, Raidal SL, Wilkes EJA, Hughes KJ. Intragastric pH of foals admitted to the intensive care unit. $J$ Vet Intern Med. 2020;34(6):2719-2726. doi:10.1111/jvim. 15888
14. Murray MJ, Mahaffey EA. Age-related characteristics of gastric squamous epithelial mucosa in foals. Equine Vet J. 1993;25 (6):514-517. doi:10.1111/j.2042-3306.1993.tb03003.x

15. Begg LM, O'Sullivan CB. The prevalence and distribution of gastric ulceration in 345 racehorses. Aust Vet J. 2003;81 (4):199-201. doi:10.1111/j.1751-0813.2003.tb11469.x

16. Bell R, Kingston J, Mogg T, Perkins N. The prevalence of gastric ulceration in racehorses in New Zealand. New Zeal Vet J. 2007;55 (1):13-18. doi:10.1080/00480169.2007.36729

17. Bezdekova B, Jahn P, Vyskocil M. Pathomorphological study on gastroduodenal ulceration in horses: localisation of lesions. Acta Vet Hung. 2007;55(2):241-249. doi:10.1556/AVet.55.2007.2.10

18. Hewetson M, Venner M, Volquardsen J, et al. Diagnostic accuracy of blood sucrose as a screening test for equine gastric ulcer syndrome (EGUS) in weanling foals. Acta Vet Scand. 2018;60 (1):24. doi:10.1186/s13028-018-0377-5

19. Luthersson N, Nielsen KH, Harris P, Parkin TD. The prevalence and anatomical distribution of equine gastric ulceration syndrome (EGUS) in 201 horses in Denmark. Equine Vet J. 2009;41 (7):619-624. doi:10.2746/042516409x441910

20. Roy MA, Vrins A, Beauchamp G, Doucet MY. Prevalence of ulcers of the squamous gastric mucosa in standardbred horses. $J$ Vet Intern Med. 2005;19(5):744-750. doi:10.1892/0891-6640(2005)19[744:pouots]2.0.co;2

21. Sandin A, Skidell J, Haggstrom J, Girma K, Nilsson G. Postmortem findings of gastric ulcers in Swedish horses up to one year of age: a retrospective study 1924-1996. Acta Vet Scand. 1999;40(2):109-120. doi:10.1186/BF03547028

22. Sandin A, Skidell J, Haggstrom J, Nilsson G. Postmortem findings of gastric ulcers in Swedish horses older than age one year: a retrospective study of 3715 horses (1924-1996). Equine Vet J. 2000;32(1):36-42. doi:10.2746/042516400777612044

23. Martineau H, Thompson H, Taylor D. Pathology of gastritis and gastric ulceration in the horse. Part 1: range of lesions present in 21 mature individuals. Equine Vet J. 2009;41(7):638-644. doi: $10.2746 / 042516409 \times 464816$

24. Becht JL, Byars TD. Gastroduodenal ulceration in foals. Equine Vet J. 1986;18(4):307-312. doi:10.1111/j.2042-3306.1986.tb0 3638.x

25. Witt $\mathrm{P}$, de Kroon L, Ankringa M, et al. Squamous gastric ulceration complicated by gastric stenosis in a foal. Equine Vet Educ. 2021. doi:10.1111/eve. 13567

26. Fléjou JF. Barrett's oesophagus: from metaplasia to dysplasia and cancer. Gut. 2005;54(Suppl 1):i6-12. doi:10.1136/gut.2004.0 41525

27. Alloway E, Linder K, May S, et al. A subset of equine gastric squamous cell carcinomas Is associated with Equus caballus papillomavirus-2 infection. Vet Pathol. 2020;57(3):427-431. doi: $10.1177 / 0300985820908797$

28. Porcellato L, Modesto P, Cappelli K, et al. Equus caballus papillomavirus type 2 (EcPV2) in co-occurring vulvar and gastric lesions of a pony. Res Vet Sci. 2020;132:167-171. doi:10.1016/j. rvsc.2020.06.003

29. Bullimore SR, Corfield AP, Hicks SJ, Goodall C, Carrington SD. Surface mucus in the non-glandular region of the equine stomach. Res Vet Sci. 2001;70(2):149-155. doi:10.1053/rvsc.2001.0455

30. Widenhouse TV, Lester GD, Merritt AM. Effect of hydrochloric acid, pepsin, or taurocholate on bioelectric properties of gastric squamous mucosa in horses. Am J Vet Res. 2002;63(5):744-749. doi:10.2460/ajvr.2002.63.744

31. Ethell MT, Hodgson DR, Hills BA. Evidence for surfactant contributing to the gastric mucosal barrier of the horse. Equine Vet J. 2000;32(6):470-474. doi:10.2746/042516400777584631

32. Aronoff N, Keegan KG, Johnson PJ, Wilson DA, Reed AL. Management of pyloric obstruction in a foal. $\mathrm{J} \mathrm{Am} \mathrm{Vet} \mathrm{Med}$ Assoc. 1997;210(7):902-905. 
33. Bezdekova B, Wohlsein P, Venner M. Chronic severe pyloric lesions in horses: 47 cases. Equine Vet J. 2020;52(2):200-204. doi:10.1111/evj.13157

34. Zedler ST, Embertson RM, Bernard WV, Barr BS, Boston RC. Surgical treatment of gastric outflow obstruction in 40 foals. Vet Surg. 2009;38(5):623-630. doi:10.1111/j.1532950X.2009.00539.x

35. Cate RE, Nielsen B, Spooner H, O'Connor-Robison C, Schott IH. Prevalence of gastric ulcers and relationship to other parameters in Standardbred racehorses. Comp Exerc Physiol. 2012;8:47-51. doi:10.3920/CEP12009

36. Busechian S, Sgorbini M, Orvieto S, et al. Evaluation of a questionnaire to detect the risk of developing ESGD or EGGD in horses. Prev Vet Med. 2021;188:105285. doi:10.1016/j. prevetmed.2021.105285

37. Sykes BW, Bowen M, Habershon-Butcher JL, Green M, Hallowell GD. Management factors and clinical implications of glandular and squamous gastric disease in horses. $J$ Vet Intern Med. 2019;33(1):233-240. doi:10.1111/jvim.15350

38. Pedersen SK, Cribb AE, Windeyer MC, et al. Risk factors for equine glandular and squamous gastric disease in show jumping Warmbloods. Equine Vet J. 2018;50(6):747-751. doi:10.1111/ evj.12949

39. Dionne RM, Vrins A, Doucet MY, Pare J. Gastric ulcers in standardbred racehorses: prevalence, lesion description, and risk factors. J Vet Intern Med. 2003;17(2):218-222. doi:10.1111/ j.1939-1676.2003.tb02437.x

40. Jonsson H, Egenvall A. Prevalence of gastric ulceration in Swedish Standardbreds in race training. Equine Vet J. 2006;38 (3):209-213. doi:10.2746/042516406776866390

41. Murray MJ, Grodinsky C, Anderson CW, Radue PF, Schmidt GR. Gastric ulcers in horses: a comparison of endoscopic findings in horses with and without clinical signs. Equine Vet J Suppl. 1989;7:68-72. doi:10.1111/j.2042-3306.1989.tb05659.x

42. Tamzali Y, Marguet C, Priymenko N, Lyazrhi F. Prevalence of gastric ulcer syndrome in high-level endurance horses. Equine Vet J. 2011;43(2):141-144. doi:10.1111/j.2042-3306.2010.00129.x

43. Hartmann AM, Frankeny RL. A preliminary investigation into the association between competition and gastric ulcer formation in non-racing performance horses. J Equine Vet Sci. 2003;23 (12):560-561. doi:10.1016/j.jevs.2003.11.007

44. Lorenzo-Figueras M, Merritt AM. Effects of exercise on gastric volume and $\mathrm{pH}$ in the proximal portion of the stomach of horses. Am J Vet Res. 2002;63(11):1481-1487. doi:10.2460/ajvr.2002.6 3.1481

45. Furr M, Taylor L, Kronfeld D. The effects of exercise training on serum gastrin responses in the horse. Cornell Vet. 1994;84 (1):41-45.

46. Luthersson N, Nielsen KH, Harris P, Parkin TD. Risk factors associated with equine gastric ulceration syndrome (EGUS) in 201 horses in Denmark. Equine Vet J. 2009;41(7):625-630. doi:10.2746/042516409X441929

47. McClure SR, Carithers DS, Gross SJ, Murray MJ. Gastric ulcer development in horses in a simulated show or training environment. $J$ Am Vet Med Assoc. 2005;227(5):775-777. doi:10.2460/javma.2005.227.775

48. Holbrook TC, Simmons RD, Payton ME, MacAllister CG. Effect of repeated oral administration of hypertonic electrolyte solution on equine gastric mucosa. Equine Vet J. 2005;37(6):501-504. doi:10.2746/042516405775314880

49. Galinelli N, Wambacq W, Broeckx BJG, Hesta M. High intake of sugars and starch, low number of meals and low roughage intake are associated with Equine Gastric Ulcer Syndrome in a Belgian cohort. J Anim Physiol Anim Nutr (Berl). 2019;105 Suppl 2:18-23. doi:10.1111/jpn.13215
50. Murray MJ, Eichorn ES. Effects of intermittent feed deprivation, intermittent feed deprivation with ranitidine administration, and stall confinement with ad libitum access to hay on gastric ulceration in horses. Am J Vet Res. 1996;57(11):1599-1603.

51. Vatistas NJ, Sifferman RL, Holste J, et al. Induction and maintenance of gastric ulceration in horses in simulated race training. Equine Vet $J$ Suppl. 1999;29:40-44. doi:10.1111/j.20423306.1999.tb05167.x

52. Smyth GB, Young DW, Hammond LS. Effects of diet and feeding on postprandial serum gastrin and insulin concentrations in adult horses. Equine Vet J Suppl. 1989;21(S7):56-59. doi:10.1111/ j.2042-3306.1989.tb05657.x

53. Murray MJ, Schusser GF, Pipers FS, Gross SJ. Factors associated with gastric lesions in thoroughbred racehorses. Equine Vet $J$. 1996;28(5):368-374. doi:10.1111/j.2042-3306.1996.tb03107.x

54. Vatistas NJ, Snyder JR, Carlson G, et al. Cross-sectional study of gastric ulcers of the squamous mucosa in thoroughbred racehorses. Equine Vet J Suppl. 1999;29:34-39. doi:10.1111/ j.2042-3306.1999.tb05166.x

55. Ricord M, Andrews FM, Yñiguez FJM, et al. Impact of concurrent treatment with omeprazole on phenylbutazone-induced equine gastric ulcer syndrome (EGUS). Equine Vet J. 2021;53 (2):356-363. doi:10.1111/evj.13323

56. Ward S, Sykes BW, Brown H, Bishop A, Penaluna LA. A comparison of the prevalence of gastric ulceration in feral and domesticated horses in the UK. Equine Vet Educ. 2015;12 (12):655-657. doi:10.1111/eve.12491

57. McGowan C, McGowan T, Andrews F, Al Jassim R. Induction and recovery of dietary induced gastric ulcers in horses. $J$ Vet Intern Med. 2011;21(3):603.

58. Elfenbein JR, Sanchez LC. Prevalence of gastric and duodenal ulceration in 691 nonsurviving foals (1995-2006). Equine Vet J Suppl. 2012;41:76-79. doi:10.1111/j.2042-3306.2011.00449.x

59. Rabuffo TS, Orsini JA, Sullivan E, et al. Associations between age or sex and prevalence of gastric ulceration in Standardbred racehorses in training. $J$ Am Vet Med Assoc. 2002;221 (8):1156-1159. doi:10.2460/javma.2002.221.1156

60. Bell RJ, Kingston JK, Mogg TD, Perkins NR. The prevalence of gastric ulceration in racehorses in New Zealand. $N Z$ Vet $J$. 2007;55(1):13-18. doi:10.1080/00480169.2007.36729

61. Nieto JE, Snyder JR, Beldomenico P, et al. Prevalence of gastric ulcers in endurance horses-a preliminary report. Vet J. 2004;167 (1):33-37. doi:10.1016/j.tvj1.2003.09.005

62. McClure SR, Glickman LT, Glickman NW. Prevalence of gastric ulcers in show horses. J Am Vet Med Assoc. 1999;215(8):1130-1133.

63. Bertone JJ. Prevalence of gastric ulcers in elite heavy use western performance horses. J Vet Intern Med. 2002;14:256-259.

64. Banse HE, MacLeod H, Crosby C, Windeyer MC. Prevalence of and risk factors for equine glandular and squamous gastric disease in polo horses. Can Vet J. 2018;59(8):880-884.

65. Chameroy KA, Nadeau JA, Bushmich SL, et al. Prevalence of non-glandular gastric ulcers in horses involved in a university riding program. $J$ Equine Vet Sci. 2006;26(5):207-211. doi:10.1016/j.jevs.2006.03.001

66. le Jeune SS, Nieto JE, Dechant JE, Snyder JR. Prevalence of gastric ulcers in Thoroughbred broodmares in pasture: a preliminary report. Vet $J$. 2009;181(3):251-255. doi:10.1016/j. tvj1.2008.03.020

67. Niedźwiedź A, Kubiak K, Nicpoń J. Endoscopic findings of the stomach in pleasure horses in Poland. Acta Vet Scand. 2013;55 (1):45. doi:10.1186/1751-0147-55-45

68. Sgorbini M, Bonelli F, Papini R, et al. Equine gastric ulcer syndrome in adult donkeys: investigation on prevalence, anatomical distribution, and severity. Equine Vet Educ. 2017;30 (4):206-210. doi:10.1111/eve.12747 
69. Lamglait B, Vandenbunder-Beltrame M, Trunet E, Lemberger K. Description of gastric ulcers and of their suspected, associated risk factors in deceased wild equids at the reserve Africaine de Sigean, France (2010-2016). J Zoo Wildl Med. 2017;48 (3):668-674. doi:10.1638/2016-0249.1

70. Murray MJ, Murray CM, Sweeney HJ, et al. Prevalence of gastric lesions in foals without signs of gastric disease: an endoscopic survey. Equine Vet J. 1990;22(1):6-8. doi:10.1111/j.2042-3306.1990. tb04193.x

71. Franklin SH, Brazil TJ, Allen KJ. Poor performance associated with equine gastric ulceration syndrome in four Thoroughbred racehorses. Equine Vet Educ. 2008;20:119-124. doi:10.2746/ 095777308X282363

72. Nieto JE, Snyder JR, Vatistas NJ, Jones JH. Effect of gastric ulceration on physiologic responses to exercise in horses. $\mathrm{Am}$ J Vet Res. 2009;70(6):787-795. doi:10.2460/ajvr.70.6.787

73. Andrews FM. Poor performance: can heartburn slow a horse? Equine Vet Educ. 2008;20(3):125-126. doi:10.2746/095777308X284000

74. Worobetz LJ, Gerrard DF. Gastrointestinal symptoms during exercise in enduro athletes: prevalence and speculations on the aetiology. N Z Med J. 1985;98(784):644-646.

75. Rodriguez-Stanley S, Bemben D, Zubaidi S, Redinger N, Miner PB Jr. Effect of esophageal acid and prophylactic rabeprazole on performance in runners. Med Sci Sports Exerc. 2006;38 (9):1659-1665. doi:10.1249/01.mss.0000229103.31521.b3

76. Herregods TV, van Hoeij FB, Oors JM, Bredenoord AJ, Smout AJ. Effect of running on gastroesophageal reflux and reflux mechanisms. Am J Gastroenterol. 2016;111(7):940-946. doi:10.1038/ajg.2016.122

77. Spanton J, Smith L, Mair T. Is Serum amyloid A elevated in horses with equine gastric ulcer syndrome? Equine Vet Educ. 2019;32(S11):16-19. doi:10.1111/eve.13145

78. Andrews F, Camacho-Luna P, Loftin P, et al. Effect of a pelleted supplement fed during and after omeprazole treatment on non-glandular gastric ulcer scores and gastric juice $\mathrm{pH}$ in horses. Equine Vet Educ. 2015;28(4):196-202. doi:10.1111/eve.12384

79. Hewetson M, Sykes BW, Hallowell GD, Tulamo RM. Diagnostic accuracy of blood sucrose as a screening test for equine gastric ulcer syndrome (EGUS) in adult horses. Acta Vet Scand. 2017;59 (1):15. doi:10.1186/s13028-017-0284-1

80. Prinsloo M, Hynd P, Franklin S, Weaver S, van den Boom R. Hair cortisol concentration is inversely related to the severity of equine squamous gastric disease. Vet J. 2019;249:58-59. doi:10.1016/j. tvj1.2019.05.009

81. Tesena P, Yingchutrakul Y, Roytrakul S, et al. Searching for serum protein markers of equine squamous gastric disease using gel electrophoresis and mass spectrometry. Equine Vet J. 2019;51 (5):581-586. doi:10.1111/evj.13068

82. Barakat C. What's your horse's ulcer risk? The horse owner's resource. Available from: https://equusmagazine.com/horse-care /whats-horses-ulcer-risk-52908. Accessed May 22, 2021.

83. Bonilla AG, Hurcombe SD, Sweeney RW, Hewetson M, Mudge MC. Small intestinal segmental volvulus in horses after gastroscopy: four cases (2011-2012). Equine Vet Educ. 2014;26 (3):141-145. doi:10.1111/eve.12100

84. Spanton JA, Smith L, Mair TS. A clinical audit of the prevalence of colic in the 48 hours after gastroscopy in 436 horses. Equine Vet Educ. 2020;32(S11):12-15. doi:10.1111/eve.13144

85. MacAllister CG, Andrews FM, Deegan E, Ruoff W, Olovson SG. A scoring system for gastric ulcers in the horse. Equine Vet $J$ 1997;29(6):430-433. doi:10.1111/j.2042-3306.1997.tb03154.x

86. Andrews FM, Sifferman RL, Bernard W, et al. Efficacy of omeprazole paste in the treatment and prevention of gastric ulcers in horses. Equine Vet J Suppl. 1999;(29):81-86. doi:10.1111/j.20423306.1999.tb05176.x
87. Bell RJ, Kingston JK, Mogg TD. A comparison of two scoring systems for endoscopic grading of gastric ulceration in horses. $N \quad Z$ Vet J. 2007;55(1):19-22. doi:10.1080/ 00480169.2007.36730

88. Wise JC, Wilkes EJA, Raidal SL, et al. Interobserver and intraobserver reliability for 2 grading systems for gastric ulcer syndrome in horses. J Vet Intern Med. 2021;35(1):571-579. doi:10.1111/jvim.15987

89. Andrews FM, Reinemeyer CR, McCracken MD, et al. Comparison of endoscopic, necropsy and histology scoring of equine gastric ulcers. Equine Vet J. 2002;34(5):475-478. doi:10.2746/042516402776117827

90. Woodward MC, Huff NK, Garza F Jr et al. Effect of pectin, lecithin, and antacid feed supplements $\left(\right.$ Egusin $^{\mathbb{B}}$ ) on gastric ulcer scores, gastric fluid $\mathrm{pH}$ and blood gas values in horses. BMC Vet Res. 2014;10(Suppl 1):S4. doi:10.1186/1746-6148-10-s1-s4

91. Armstrong D. Review article: gastric $\mathrm{pH}$ - the most relevant predictor of benefit in reflux disease? Aliment Pharmacol Ther. 2004;20 Suppl 5:19-26. doi:10.1111/j.1365-2036.2004.02140.x

92. Bell NJ, Burget D, Howden CW, Wilkinson J, Hunt RH. Appropriate acid suppression for the management of gastro-oesophageal reflux disease. Digestion. 1992;51(Suppl 1):59-67. doi:10.1159/000200917

93. Merritt AM, Sanchez LC, Burrow JA, Church M, Ludzia S. Effect of GastroGard and three compounded oral omeprazole preparations on $24 \mathrm{~h}$ intragastric $\mathrm{pH}$ in gastrically cannulated mature horses. Equine Vet J. 2003;35(7):691-695. doi:10.2746/ 042516403775696339

94. Wise JC, Hughes KJ, Edwards S, et al. Pharmacokinetic and pharmacodynamic effects of 2 registered omeprazole preparations and varying dose rates in horses. $J$ Vet Intern Med. 2021;35 (1):620-631. doi:10.1111/jvim.15971

95. Sykes BW, Underwood C, Greer R, McGowan CM, Mills PC. The effects of dose and diet on the pharmacodynamics of omeprazole in the horse. Equine Vet J. 2017;49(4):525-531. doi:10.1111/evj.12630

96. Sykes BW, Underwood C, McGowan CM, Mills PC. Pharmacokinetics of intravenous, plain oral and enteric-coated oral omeprazole in the horse. J Vet Pharmacol Ther. 2015;38 (2):130-136. doi:10.1111/jvp.12169

97. Daurio CP, Holste JE, Andrews FM, et al. Effect of omeprazole paste on gastric acid secretion in horses. Equine Vet J Suppl. 1999;29:59-62. doi:10.1111/j.2042-3306.1999.tb05171.x

98. Sykes BW, Sykes KM, Hallowell GD. A comparison of three doses of omeprazole in the treatment of equine gastric ulcer syndrome: a blinded, randomised, dose-response clinical trial. Equine Vet J. 2015;47(3):285-290. doi:10.1111/evj.12287

99. Sykes BW, Underwood C, Greer R, McGowan CM, Mills PC. Pharmacokinetics and bioequivalence testing of five commercial formulations of omeprazole in the horse. J Vet Pharmacol Ther. 2016;39(1):78-83. doi:10.1111/jvp.12240

100. Gough S, Hallowell G, Rendle D. A study investigating the treatment of equine squamous gastric disease with long-acting injectable or oral omeprazole. Vet Med Sci. 2020;6(2):235-241. doi:10.1002/vms3.220

101. Doucet MY, Vrins AA, Dionne R, Alva R, Ericsson G. Efficacy of a paste formulation of omeprazole for the treatment of naturally occurring gastric ulcers in training standardbred racehorses in Canada. Can Vet J. 2003;44(7):581-585.

102. MacAllister CG, Sifferman RL, McClure SR, et al. Effects of omeprazole paste on healing of spontaneous gastric ulcers in horses and foals: a field trial. Equine Vet $J$ Suppl. 1999;29:77-80. doi:10.1111/j.2042-3306.1999.tb05175.x

103. Murray MJ, Haven ML, Eichorn ES, et al. Effects of omeprazole on healing of naturally-occurring gastric ulcers in thoroughbred racehorses. Equine Vet J. 1997;29(6):425-429. doi:10.1111/ j.2042-3306.1997.tb03153.x 
104. Kerbyson N, Knottenbelt DK, Carslake HB, et al. A comparison between omeprazole and a dietary supplement for the management of squamous gastric ulceration in horses. J Equine Vet Sci. 2016;40:94-101. doi:10.1016/j.jevs.2016.02.228

105. Andrews FM, Frank N, Sommardahl CS, et al. Effects of intravenously administrated omeprazole on gastric juice $\mathrm{pH}$ and gastric ulcer scores in adult horses. J Vet Intern Med. 2006;20(5):1202-1206. doi:10.1892/ 0891-6640(2006)20[1202:eoiaoo]2.0.co;2

106. Sykes BW, Kathawala K, Song Y, et al. Preliminary investigations into a novel, long-acting, injectable, intramuscular formulation of omeprazole in the horse. Equine Vet J. 2017;49(6):795-801. doi:10.1111/evj.12688

107. Sykes BW, Sykes KM, Hallowell GD. A comparison between pre- and post exercise administration of omeprazole in the treatment of equine gastric ulcer syndrome: a blinded, randomised, clinical trial. Equine Vet J. 2014;46(4):422-426. doi:10.1111/ evj. 12083

108. Sykes BW, Sykes K, Hallowell GD. Comparison of the effect of two doses of omeprazole on the squamous gastric mucosa in thoroughbred racehorses. Vet Rec. 2014;175(10):249. doi:10.1136/vr.102622

109. Andersson T, Hassan-Alin M, Hasselgren G, Röhss K, Weidolf L. Pharmacokinetic studies with esomeprazole, the (S)-isomer of omeprazole. Clin Pharmacokinet. 2001;40(6):411-426. doi:10.2165/00003088-200140060-00003

110. Edwards SJ, Lind T, Lundell L. Systematic review: proton pump inhibitors (PPIs) for the healing of reflux oesophagitis a comparison of esomeprazole with other PPIs. Aliment Pharmacol Ther. 2006;24(5):743-750. doi:10.1111/j.1365-2036.2006.03074.x

111. McNicholl AG, Linares PM, Nyssen OP, Calvet X, Gisbert JP. Meta-analysis: esomeprazole or rabeprazole vs. first-generation pump inhibitors in the treatment of Helicobacter pylori infection. Aliment Pharmacol Ther. 2012;36(5):414-425. doi:10.1111/j.1365-2036.2012.05211.x

112. Videla R, Sommardahl CS, Elliott SB, Vasili A, Andrews FM. Effects of intravenously administered esomeprazole sodium on gastric juice $\mathrm{pH}$ in adult female horses. $J$ Vet Intern Med. 2011;25 (3):558-562. doi:10.1111/j.1939-1676.2011.0716.x

113. Pereira MC, Levy FL, Valadão CAA, Ferraz GC, Queiroz-Neto A. Preliminary study of the gastric acidity in thoroughbred horses at rest after enteral administration of esomeprazole magnesium (Nexium). J Equine Vet Sci. 2009;29(11):791-794. doi:10.1016/j. jevs.2009.10.006

114. Sykes BW, Underwood C, Mills PC. The effects of dose and diet on the pharmacodynamics of esomeprazole in the horse. Equine Vet J. 2017;49(5):637-642. doi:10.1111/evj.12670

115. Huxford KE, Dart AJ, Perkins NR, Bell R, Jeffcott LB. A pilot study comparing the effect of orally administered esomeprazole and omeprazole on gastric fluid $\mathrm{pH}$ in horses. $N$ Z Vet J. 2017;65 (6):318-321. doi:10.1080/00480169.2017.1359125

116. Rendle DI. Oral esomeprazole as a treatment for equine gastric ulcer syndrome refractory to oral omeprazole. Equine Vet $J$. 2017;49(S51):25-26. doi:10.1111/evj.47 12732

117. Ryan CA, Sanchez LC, Giguère S, Vickroy T. Pharmacokinetics and pharmacodynamics of pantoprazole in clinically normal neonatal foals. Equine Vet J. 2005;37(4):336-341. doi:10.2746/ 0425164054529427

118. Fontecha-Barriuso M, Martín-Sanchez D, Martinez-Moreno JM, et al. Molecular pathways driving omeprazole nephrotoxicity. Redox Biol. 2020;32:101464. doi:10.1016/j.redox.2020.101464

119. Heidelbaugh JJ. Proton pump inhibitors and risk of vitamin and mineral deficiency: evidence and clinical implications. Ther $A d v$ Drug Saf. 2013;4(3):125-133. doi:10.1177/2042098613482484

120. Pagan JD, Petroski-Rose L, Mann A, Hauss A. Omeprazole reduces calcium digestibility in Thoroughbred horses. $J$ Equine Vet Sci. 2020;86:102851. doi:10.1016/j.jevs.2019.102851
121. Caston SS, Fredericks DC, Kersh KD, Wang C. Short-term omeprazole use does not affect serum calcium concentrations and bone density in horses. J Equine Vet Sci. 2015;35(9):714-723. doi:10.1016/j.jevs.2015.07.003

122. Brusselaers N, Wahlin K, Engstrand L, Lagergren J. Maintenance therapy with proton pump inhibitors and risk of gastric cancer: a nationwide population-based cohort study in Sweden. BMJ Open. 2017;7(10):e017739. doi:10.1136/bmjopen-2017-017739

123. Sojka JE, Weiss JS, Samuels ML, You GM. Effect of the somatostatin analogue octreotide on gastric fluid $\mathrm{pH}$ in ponies. $\mathrm{Am}$ $J$ Vet Res. 1992;53(10):1818-1821.

124. Reimer C, Søndergaard B, Hilsted L, Bytzer P. Proton-pump inhibitor therapy induces acid-related symptoms in healthy volunteers after withdrawal of therapy. Gastroenterology. 2009;137 (1):80-87. doi:10.1053/j.gastro.2009.03.058

125. Mason LV, Moroney JR, Mason RJ. Prophylactic therapy with omeprazole for prevention of equine gastric ulcer syndrome (EGUS) in horses in active training: a meta-analysis. Equine Vet J. 2019;51(1):11-19. doi:10.1111/evj.12951

126. Murray MJ, Grodinsky C. The effects of famotidine, ranitidine and magnesium hydroxide/aluminium hydroxide on gastric fluid $\mathrm{pH}$ in adult horses. Equine Vet $J$ Suppl. 1992;11:52-55. doi:10.1111/j.2042-3306.1992.tb04773.x

127. Lester GD, Smith RL, Robertson ID. Effects of treatment with omeprazole or ranitidine on gastric squamous ulceration in racing Thoroughbreds. J Am Vet Med Assoc. 2005;227(10):1636-1639. doi:10.2460/javma.2005.227.1636

128. Nieto JE, Spier SJ, van Hoogmoed L, et al. Comparison of omeprazole and cimetidine in healing of gastric ulcers and prevention of recurrence in horses. Equine Vet Educ. 2001;13 (5):260-264. doi:10.1111/j.2042-3292.2001.tb00105.x

129. Shibli F, Kitayama Y, Fass R. Novel therapies for gastroesophageal reflux disease: beyond proton pump inhibitors. Curr Gastroenterol Rep. 2020;22(4):16. doi:10.1007/s11894-020-0753-y

130. Yamashita H, Kanamori A, Kano C, et al. The effects of switching to vonoprazan, a novel potassium-competitive acid blocker, on gastric acidity and reflux patterns in patients with erosive esophagitis refractory to proton pump Inhibitors. Digestion. 2017;96(1):52-59. doi:10.1159/000478255

131. Harris PA, Coenen M, Geor RJ. Controversial areas in equine nutrition and feeding management: the Editors' views. In: Geor RJ, Harris PA, Coenen M, editors. Equine Applied and Clinical Nutrition. W.B. Saunders; 2013:455-465.

132. Clark CK, Merritt AM, Burrow JA, Steible CK. Effect of aluminum hydroxide/magnesium hydroxide antacid and bismuth subsalicylate on gastric pH in horses. J Am Vet Med Assoc. 1996;208(10):16871691.

133. Murray MJ, Grady TC. The effect of a pectin-lecithin complex on prevention of gastric mucosal lesions induced by feed deprivation in ponies. Equine Vet J. 2002;34(2):195-198. doi:10.2746/ 042516402776767268

134. Venner M, Lauffs S, Deegen E. Treatment of gastric lesions in horses with pectin-lecithin complex. Equine Vet J Suppl. 1999;29:91-96. doi:10.1111/j.2042-3306.1999.tb05178.x

135. Sanz MG, Viljoen A, Saulez MN, Olorunju S, Andrews FM. Efficacy of a pectin-lecithin complex for treatment and prevention of gastric ulcers in horses. Vet Rec. 2014;175(6):147. doi:10.1136/ vr.102359

136. Sykes BW, Sykes KM, Hallowell GD. Efficacy of a combination of a unique pectin-lecithin complex (Apolectol ${ }^{\mathbb{B}}$ ), live yeast and magnesium hydroxide in the prevention of EGUS and faecal acidosis in Thoroughbred racehorses: a randomised, blinded, placebo controlled clinical trial. Equine Vet J. 2013;45(S44):13. doi:10.1111/evj.12145_32 
137. Camacho-Luna P, Andrews FM, Keowen ML, et al. The effect of porcine hydrolysed collagen on gastric ulcer scores, gastric juice $\mathrm{pH}$, gastrin and amino acid concentrations in horses. Equine Vet Educ. 2020. doi:10.1111/eve.13409

138. Huff NK, Auer AD, Garza F Jr, et al. Effect of sea buckthorn berries and pulp in a liquid emulsion on gastric ulcer scores and gastric juice $\mathrm{pH}$ in horses. $J$ Vet Intern Med. 2012;26 (5):1186-1191. doi:10.1111/j.1939-1676.2012.00975.x

139. Bush J, van den Boom R, Franklin S. Comparison of aloe vera and omeprazole in the treatment of equine gastric ulcer syndrome. Equine Vet J. 2018;50(1):34-40. doi:10.1111/evj.12706

140. Munsterman AS, Dias Moreira AS, Marqués FJ. Evaluation of a Chinese herbal supplement on equine squamous gastric disease and gastric fluid $\mathrm{pH}$ in mares. J Vet Intern Med. 2019;33 (5):2280-2285. doi:10.1111/jvim.15603

141. van Erck-westergren E, Ter Woort F. Diet-induced changes in gastric and faecal microbiota in horses: association with gastric ulcer healing. Equine Vet J. 2019;51(S53):21. doi:10.1111/evj.34_13152

142. Luthersson N, Bolger C, Fores $P$, et al. Effect of changing diet on gastric ulceration in exercising horses and ponies after cessation of omeprazole treatment. J Equine Vet Sci. 2019;83:102742. doi:10.1016/j.jevs.2019.05.007
143. Frank N, Andrews FM, Elliott SB, Lew J. Effects of dietary oils on the development of gastric ulcers in mares. Am J Vet Res. 2005;66(11):2006-2011. doi:10.2460/ajvr.2005.66.2006

144. Cargile JL, Burrow JA, Kim I, Cohen ND, Merritt AM. Effect of dietary corn oil supplementation on equine gastric fluid acid, sodium, and prostaglandin E2 content before and during pentagastrin infusion. $J$ Vet Intern Med. 2004;18(4):545-549. doi:10.1892/0891-6640(2004)18<545:eodcos $>2.0 . \operatorname{co} ; 2$

145. Martínez JR, Zuluaga AM, Silveira GE. Effects of corn oil on the gastric mucosa of horses with induced ulcer. Revista Colombiana de Ciencias Pecuarias. 2016;29:138-148. doi:10.17533/udea.rccp. v29n2a07

146. Bass L, Swain E, Santos H, Hess T, Black J. Effects of feeding frequency using a commercial automated feeding device on gastric ulceration in exercised quarter horses. J Equine Vet Sci. 2018;64:96-100. doi:10.1016/j.jevs.2018.02.005

\section{Publish your work in this journal}

Veterinary Medicine: Research and Reports is an international, peerreviewed, open access journal publishing original research, case reports, editorials, reviews and commentaries on all areas of veterinary medicine. The manuscript management system is completely online and includes a very quick and fair peer-review system. Visit http://www.dovepress.com/testimonials.php to read real quotes from published authors.

Submit your manuscript here: http://www.dovepress.com/veterinary-medicine-research-and-reports-journal 